University of Louisville

ThinkIR: The University of Louisville's Institutional Repository

Electronic Theses and Dissertations

$12-2017$

\title{
James Franklin Bell : hard war in the Philippines.
}

Daniel Michael

University of Louisville

Follow this and additional works at: https://ir.library.louisville.edu/etd

Part of the Military History Commons

\section{Recommended Citation}

Michael, Daniel, "James Franklin Bell : hard war in the Philippines." (2017). Electronic Theses and Dissertations. Paper 2853.

https://doi.org/10.18297/etd/2853

This Master's Thesis is brought to you for free and open access by ThinkIR: The University of Louisville's Institutional Repository. It has been accepted for inclusion in Electronic Theses and Dissertations by an authorized administrator of ThinkIR: The University of Louisville's Institutional Repository. This title appears here courtesy of the author, who has retained all other copyrights. For more information, please contact thinkir@louisville.edu. 
JAMES FRANKLIN BELL: HARD WAR IN THE PHILIPPINES

By

Daniel Michael

B.A. Cedarville University 2010

A Thesis Submitted to the Faculty of the College of Arts and Sciences of the University of Louisville In Partial Fulfillment of the Requirements for the Degree of

\author{
Master of Arts \\ in History
}

Department of History University of Louisville Louisville, Kentucky

December 2017 



\section{JAMES FRANKLIN BELL: HARD WAR IN THE PHILIPPINES}

By

Daniel Michael

B.A., Cedarville University, 2010

A Thesis Approved on

$11 / 21 / 2017$

by the following Thesis Committee

Dr. Daniel Krebs

Dr. Thomas Mackey

Dr. Julie Bunck 


\section{DEDICATION}

This thesis is dedicated to my parents,

Mr. George Michael

and

Mrs. Cheryl Michael

For their encouragement, support, and inspiration. 


\section{ACKNOWLEDGEMENTS}

I would like to thank my advisor Dr. Daniel Krebs for his guidance and teaching during my time at the University of Louisville and for his seemingly endless amounts of patience as I wrote this thesis. I would also like to thank Dr. Thomas Mackey and Dr.

Julie Bunck for serving on my committee and providing valuable insight into my topic. I am in debt to my family, friends, and colleagues who have helped and encouraged me along the way. I also am grateful for the many colleagues at the Frazier History Museum and Buffalo Bill Center of the West I have had the privilege to work with as I get started in my public history career. 


\section{ABSTRACT \\ JAMES FRANKLIN BELL: HARD WAR IN THE PHILIPPINES \\ Daniel Michael}

$11 / 21 / 2017$

This thesis surveys the military history of the Philippine-American War of 18991902. In particular, this thesis looks at that war through the lens of hard war as a way of war. It begins with an introduction to hard war as a concept and a historiography of the Philippine-American War and continues with an overview of the events leading up to the war. The first two chapters deal with the wider role of the U.S. Army during the war, while the third chapter examines the role of James Franklin Bell, and American officer, and his command of the Third Separate Brigade in Batangas Province. This thesis is an attempt to place the Philippine-American War into the discussion of hard war in American military history. 


\section{TABLE OF CONTENTS}

Acknowledgements.......................................................

Abstract................................................................

Introduction. .........................................................

Ways of Hard War............................................

Outline.......................................................8

Sources and Historiography..................................11

Chapter 1: Conventional War ........................................ 16

From Spanish-American to Philippine American......................24

Problems Within the Army of Liberation.............................36

Aguinaldo's Defeat.........................................42

Chapter 2: Irregular War...............................................49

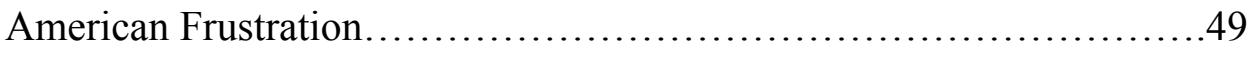

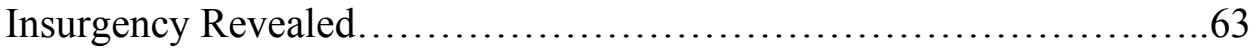

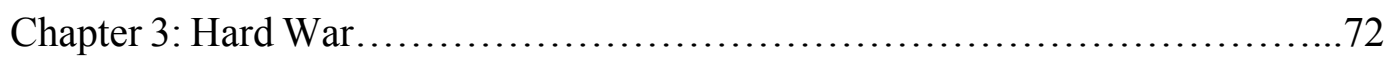

Bell's War........................................................

Conclusion.......................................................98

References......................................................... 105

Curriculum Vitae...................................................... 112 


\section{INTRODUCTION}

Between 1899 and 1902, the U.S. Army fought an often-overlooked war to establish American control of the Philippines. The Philippine-American War followed the Spanish-American War, but despite being larger in scale, the Philippine-American War has been called a "hidden war."1 This is not for lack of involvement, because at its height 70,000 U.S. troops were stationed in the Philippines. When President Theodore Roosevelt finally declared victory in July 1902, the U.S. Army's mission was not finished. America was only beginning its colonial rule of the Philippines, which lasted until the Second World War and included a sizable U.S. military presence on the islands. Despite the U.S. declaration of victory, combat operations to pacify the Philippines continued well past 1902. The Army had pacified the Northern and largely Catholic segments of the Philippines but still fought a campaign against the Muslim Moro people in the Southern Philippines until 1913. ${ }^{2}$

The Philippine-American War should not be remembered as a sidebar to the Spanish-American War. It is far more complex. In fact, while the Spanish-American War remained limited in scope and only lasted a few months, American fighting in the

\footnotetext{
${ }^{1}$ Leon Wolff, Little Brown Brother: How the United States Purchased and Pacified the Philippine Islands at the Century's Turn (New York, N.Y.: History Book Club, 2006), ix.

${ }^{2}$ James R. Arnold, The Moro War: How America Battled a Muslim Insurgency in the Philippine Jungle, 1902-1913, First Edition (Bloomsbury Press, 2011). For further reading on the Moro War, see James Arnold's work on the subject.
} 
Philippines was larger in scale and turned into counter-insurgnecy warfare lasting for years. Because the Army adapted to fight a hard war ${ }^{3}$ in the Philippines in response to an insurgency, the war was not an exception to the American way of war - and certainly was not just about garrison duty. Instead, this paper will argue that the Philippine-American War shows how the U.S. Army resorted to hard war in order to achieve victory after decisive battles did not defeat the Filipinos.

Of the American commanders in the Philippine-American War, James Franklin Bell is perhaps the clearest practitioner of hard war tactics. Bell was not only a model soldier - he won a Medal of Honor in 1899 for single-handedly capturing several Filipino insurgents while leading a patrol - he was also a career soldier who conducted a successful counterinsurgency campaign in Batangas province between December 1901 and May 1902. His campaign ended Filipino resistance in the region and was hailed by Bell's peers. However, he was also criticized for the hardships the campaign placed on the Filipino people. This thesis will show how the Philippine-American War became a hard war, and how James Franklin Bell practiced hard war in Batangas province.

\section{WAYS OF HARD WAR}

Understanding hard war and how it fits into the idea of an American way of war requires context. One of the groundbreaking works arguing for an American way of war was published in 1973. Russell Weigley's The American Way of War: A History of United States Military Strategy and Policy examined American military history from the

\footnotetext{
${ }^{3}$ The terms "hard war" and "American way of war" will be explained and discussed further in the introduction.
} 
American Revolution to the Vietnam War. ${ }^{4}$ For Weigley, the U.S. Civil War ushered in a new period of American warfare. When General Sherman took his Union forces on the infamous March to the Sea in late 1864 - destroying railroads, taking food and livestock, and burning houses and barns - thus making Southerners "feel the hard hand of war," he also shaped an American way of war that, later fully realized, became total war. The U.S. military began to shift from waging wars of attrition to waging wars of annihilation. From the Civil War onward, military strategy utilized full mobilization of society and the economy to achieve total victory. For Weigley, such an American way of war only emerged once the nation had sufficient military power, following the industrialization of the economy and after a strong federal state had developed. Earlier conflicts, on the other hand, were limited by the scope of America's military capability. ${ }^{5}$

Weigly's thesis, though, relied on two kinds of war: limited war and a complete overthrow of the enemy. ${ }^{6}$ Yet American military history is filled with examples, as even Weigley admits, that do not neatly fit into those two categories. Mark Grimsley's book, The Hard Hand of War: Union Military Policy Toward Southern Civilians 1861-1865, ${ }^{7}$ argued instead that Union treatment of Southern noncombatants blended a mix of destruction aimed at civilian property and the Southern economy, while exercising restraint for the actual lives of Southern civilians. Initially, Grimsely argues, the Union adopted a conciliatory policy towards the South. This policy changed over time towards

\footnotetext{
${ }^{4}$ Russell F. Weigley, The American Way of War: A History of United States Military Strategy and Policy (Bloomington: Indiana University Press, 1977).

${ }^{5}$ Russell F. Weigley, The American Way of War: A History of United States Military Strategy and Policy (Bloomington: Indiana University Press, 1977), xx-xxiii.

${ }^{6}$ Ibid., xx-xxi.

${ }^{7}$ Mark Grimsley, The Hard Hand of War (Cambridge: Cambridge University Press, 1997).
} 
coercion, and Sherman's raid became a centerpiece by using destruction aimed at the Southern economy while maintaining a degree of restraint. ${ }^{8}$

In fact, Grimsley offers a definition of hard war that applies just as much to Bell in the Philippine-American War as it does to Generals Sherman or Sheridan during the U.S. Civil War: “The erosion of the enemy's will to resist by deliberately or concomitantly subjecting the civilian population to the pressures of war." And while the Union army had a wide range of acceptable targets, it understood limits to its destruction. Both in the Civil War, as Grimsley argued, and during Bell's campaign in the Philippines the U.S. Army was willing to resort to hard war. ${ }^{10}$

Unlike Weigley, Brian Linn in his The Echo of Battle: The Army's Way of War ${ }^{11}$ in 2007 argued that "small" and "unconventional wars" - and not just major conflicts such as the U.S. Civil War or peacetime defense policies and strategies - also shaped the American way of war. Similarly, Max Boot's 2002 book The Savage Wars of Peace: Small Wars and the Rise of American Power ${ }^{12}$ also examined wars that were small in scale. Even more important, as Boot argued, these types of conflicts occurred far more often than those major conflicts that Weigley and many others most often identified with the American way of war. Boot thereby used a nineteenth-century British officer's definition to explain small wars as "campaigns undertaken to suppress rebellions and

\footnotetext{
${ }^{8}$ Ibid., 208-15.

${ }^{9}$ Ibid., 5 .

${ }^{10}$ Ibid., 4-5.

${ }^{11}$ Brian McAllister Linn, The Echo of Battle: The Army's Way of War (Cambridge, Mass. ; London: Harvard University Press, 2007).

${ }^{12}$ Max Boot, The Savage Wars of Peace: Small Wars and the Rise of American Power, Revised Edition (New York: Basic Books, 2014).
} 
guerrilla warfare in all parts of the world where organized armies are struggling against opponents who will not meet them in the open field."13

While Grimsley, Boot, and Linn offered nuance or counterpoint to Weigley's thesis, a more recent work set out to cover territory uncharted by Weigley. In 2008 John Grenier added his work, The First Way of War: American Warmaking on the Frontier. ${ }^{14}$ In it, Grenier argued that colonial and early national American ways of war had a distinct nature. These wars even approached the wars of annihilation that Weigley contended only emerged later in American history. Grenier made the case that English colonists and early Americans carried out extirpative war against American Indians. When colonists struggled to defeat American Indians in battle, they resorted to attacking non-combatants, villages, and food supplies. This kind of war resembled hard war, and at points became war of annihilation. $^{15}$

Hard war in the American lexicon became defined as a rejection of conventional battles between armies, instead granting legitimacy to attacking the enemy's economy and inflicting hardship upon civilians. ${ }^{16}$ As General Philip Sheridan stated,

"Death is popularly considered the maximum of punishment in war, but it is not; reduction to poverty brings prayers for peace more surely and more quickly than does the destruction of human life, as the selfishness of man has demonstrated in more than one great conflict.",17

\footnotetext{
${ }^{13}$ Ibid., xvii.

${ }^{14}$ John Grenier, The First Way of War: American War Making on the Frontier, 1607-1814, First Edition (Cambridge: Cambridge University Press, 2008).

${ }^{15}$ See also, Linn, The Echo of Battle, 69.

${ }^{16}$ Matthew Carr, Sherman's Ghosts: Soldiers, Civilians, and the American Way of War (New York: The New Press, 2015), 28.

${ }^{17}$ Ibid, 27-28.
} 
Almost 40 years before Bell, General William Sherman carried out this type of war in the South during the American Civil War. He attacked the southern economy directly, even ignoring the major Confederate forces left operating against him. Contemporary to Sherman, General Sheridan carried out a similar campaign in the Shenandoah Valley in mid-1864. Prior to the Civil War, both Sherman and Sheridan had experienced the nation's frontier way of war, as they each fought against American Indians and served in garrison duty. They brought this experience to the Civil War and adapted lessons from the frontier to their campaigns against the South. ${ }^{18}$ They attacked the enemy's economy, logistics, and stamina, not just the enemy's army. And they maneuvered to break not only the South's ability but also the South's will to fight. ${ }^{19}$

In the American West in the nineteenth century, the government also pursued policies designed to control Native Americans by limiting their movement and destroying one of their main food sources, buffalo. This indirect way of dealing with Native Americans was devastating to their population and greatly reduced their ability to fight. Two 2016 books demonstrate the way that the U.S. Army conducted warfare against Native Americans. Peter Cozzens' The Earth is Weeping: The Epic Story of the Indian Wars for the American West ${ }^{20}$ and David Silverman's Thundersticks: Firearms and the Violent Transformation of Native America ${ }^{21}$ both demonstrate the hard wars that the Army carried out on the frontier. As Silverman contends, native warriors could contend

\footnotetext{
${ }^{18}$ Linn, The Echo of Battle, 75-76.

${ }^{19}$ Carr, Sherman's Ghosts, 54-59.

${ }^{20}$ Peter Cozzens, The Earth Is Weeping: The Epic Story of the Indian Wars for the American West, First Edition (New York: Knopf, 2016).

${ }^{21}$ David J. Silverman, Thundersticks: Firearms and the Violent Transformation of Native America (Cambridge, Massachusetts ; London, England: Belknap Press: An Imprint of Harvard University Press, 2016).
} 
with the U.S. cavalry when close to even terms, but they could not resist the damage done when the Army attacked their people, homes, and food. ${ }^{22}$

The campaigns of the Civil War and the American West were well known to Bell. He graduated from West Point in the decades following the Civil War and was twice assigned to the infamous 7th Cavalry Regiment. As this thesis argues, Bell is linked to a wider American way of war by his own hard war that he waged against the Philippine Insurrection in the winter of 1901-1902. He directed force against the insurgent's civilian support. Bell gained control of the population by forcing them into U.S. controlled "reconcentration zones" and attacked the Filipinos' ability to wage war by destroying their resources, especially food.

The following pages will show how Bell's campaign in Batangas was an example of hard war and how the Philippine-American war evolved into that level of conflict. While it stopped short of the extirpative wars against American Indians, it moved far beyond a limited war. Bell's campaign in Batangas defeated one of the last major Filipino holdouts, but also brought terrible suffering to the Filipino population. By exposing civilians to the violence of the conflict, Bell and the U.S. Army resorted to a strategy common to other American wars, both before and after it. Hard war in American military history can trace its roots to the colonial era, and Bell's campaign was another step in that long line of hard wars. Bell represents a common thread running through many American conflicts.

\footnotetext{
${ }^{22}$ Ibid., 2.
} 


\section{OUTLINE}

This thesis is a case study of the Philippine-American War as a hard war and James Franklin Bell's key role in this conflict. Far from a simple handover from Spain or occupational duty for the American Army, the conflict in the Philippines was a complex and violent undertaking. However, because of the limited scope of this project, the following chapters will not explore in full the Filipino Army ${ }^{23}$ and insurrection in its entirety. ${ }^{24}$ As much as they deserve scholarly work, this thesis is about the U.S. and Bell's role in the conflict. This thesis is neither about American public opinion about the war, nor foreign policy at home. ${ }^{25}$ Similarly, it would have been outside the scope of this project to deal fully with national ${ }^{26}$ or individual identity ${ }^{27}$ in this conflict.

This paper is primarily about American military operations in the Philippines during 1898-1902, as such it avoids many other interesting and relevant topics which deserve treatment. However, one important topic cannot be avoided because of how thoroughly embedded in the subject it became. Race and the racism of the day were central to American understandings of the war. This was a racially charged conflict. ${ }^{28}$ Both in the way that American soldiers dealt with Filipinos and in the administration's

\footnotetext{
${ }^{23}$ Luis Camara Dery, The Army of the First Philippine Republic and Other Historical Essays (Malate, Manila, Philippines: De La Salle University Press, 1995).

${ }^{24}$ O. D. Corpuz, The Roots of the Filipino Nation. Two Volumes, 2nd Edition (Aklahi Foundation, Inc., 1989).

${ }^{25}$ Richard E. Welch, Response to Imperialism: The United States and the Philippine-American War, 18991902, First Edition (Chapel Hill: The University of North Carolina Press, 1979).

${ }^{26}$ Stanley Karnow, In Our Image: America's Empire in the Philippines, 1989.

${ }^{27}$ Kristin L. Hoganson, Fighting for American Manhood: How Gender Politics Provoked the SpanishAmerican and Philippine-American Wars, 6th Edition (New Haven: Yale University Press, 2000).

${ }^{28}$ Willard B. Gatewood Jr, Black Americans and the White Man's Burden, 1898-1903, First Edition (Urbana: University of Illinois Press, 1975).
} 
policies towards the islands. From enlisted men to general officers, soldiers viewed the Filipinos as lesser and frequently stated so explicitly. It is important to remember these attitudes when discussing the level of destruction that American soldiers carried out during the war and the lack of punishment for the excesses that came with that destruction.

Officials and the public back home did not consider the Filipinos capable of selfrule which went hand in hand with the imperialism of the time. Racism towards, and mistreatment of Filipinos created contradictions for African-Americans, both in the United States and those that were ordered to the Philippines as part of segregated units. Observing a country that was unwilling to treat them as citizens, they had to also fight to expand control over other people who Americans did not treat as equal. ${ }^{29}$

What the reader will encounter is an account of the Philippine-American War centered around James Franklin Bell. The first chapter is an overview of how the war began, from the Battle of Manila Bay in May,1898 until the dissolution of the Filipino Revolutionary Army in December 1899. The second chapter is an examination of how the war changed from a conventional conflict between two standing armies in 1899 into a guerrilla or counter-insurgency war in early 1900. This chapter examines the American response to that shift and concludes by showing how the Americans found success by the summer of 1901. The third chapter is an examination of James Franklin Bell's hard war in Batangas Province in Southern Luzon between December 1901 and May 1902.

\footnotetext{
${ }^{29}$ David J. Silbey, A War of Frontier and Empire: The Philippine-American War, 1899-1902, First Edition (New York: Hill and Wang, 2008), 108-109.
} 
Together the three chapters will show that the Philippine-American War might have begun as a conventional conflict, limited in scope, but soon became a counterinsurgency war when the defeat of the Filipino Revolutionary Army failed to end resistance to U.S. occupation. The U.S. then fought this new conflict by resorting to hard war tactics, taken to their fullest measure by James Franklin Bell in Batangas province.

In both this introduction and throughout, this thesis uses the term PhilippineAmerican War. ${ }^{30}$ But the name Philippine-American War describes more than one unified event. Initially, the conflict involved Filipinos and Americans fighting together. During the period from February 1899 until December 1899, two organized field armies fought each other in conventional terms. By 1900, the war had turned into a guerrilla war as Filipino leadership dissolved their field army in the face of severe losses. Where applicable, this thesis uses the name Filipino Revolutionary Army. However, because of the nature of the war after December 1899, the thesis introduces the terms insurrection, insurgents, or insurgency to describe Filipino combatants. Another term, pacification, is how journalists, soldiers, and even those at home referred to the war at the time. ${ }^{31}$ The common usage of both pacification and insurrection influenced the decision to use those terms, even if they do not fully represent the nature of the conflict. This thesis does not intend to glorify the American Army or Bell's success in the war. Instead, it will attempt to argue that the success they achieved was linked to the kind of war they fought. The thesis will also argue that although this may be a limited study of operations and tactics in

\footnotetext{
${ }^{30}$ David J. Silbey, A War of Frontier and Empire: The Philippine-American War, 1899-1902, First Edition (New York: Hill and Wang, 2008), i-xviii. For additional discussion of the issues surrounding how historians refer to the conflict Silbey's introduction offers a thoughtful analysis.

${ }^{31}$ Gregg Jones, Honor in the Dust: Theodore Roosevelt, War in the Philippines, and the Rise and Fall of America's Imperial Dream, First Edition (New York: NAL, 2012), 204.
} 
one American conflict at the end of the nineteenth century. Bell's campaign sheds light on and offers lessons about other U.S. conflicts.

\section{SOURCES AND HISTORIOGRAPHY}

For primary material, this thesis relied on Bell's papers, which are housed at the U.S. Army War College in Carlisle, Pennsylvania. ${ }^{32}$ The documents in the collection are his original telegraphic circulars, written commands to subordinates as a General Officer that dictated how Bell fought a counter-insurgency. Bell's orders show how he implemented hard war in Batangas Province, and while they are only limited to his official role and not his personal writings, he details both the reasoning behind his orders along with the specifics of how his subordinates should carry them out.

Various regimental histories appeared throughout the first half of the twentieth century, but 1939 saw the first history of the Philippine-American War. William Sexton published his work Soldiers in the Sun: An Adventure in Imperialism that year. ${ }^{33}$ Sexton largely defended American actions in the Philippines and he attributed American military success to the capabilities of junior officers and enlisted soldiers. He acknowledged that there were some excesses by American troops, but that they were limited in scale. He asserted that the reconcentration camps were humane and that suffering could be blamed on continued resistance but did not attribute the use of reconcentration zones as a deciding factor in the conflict. Sexton's work is predominantly a traditional military

\footnotetext{
32 James Franklin Bell, Adna Romanza Chaffee, and Lloyd Wheaton, James Franklin Bell Papers, 1902, U.S. Army Military History Institute.

${ }^{33}$ Sexton, William T., Soldiers in the Sun: An Adventure in Imperialism (Harrisburg, PA: The Military Service Publishing Company, 1939).
} 
history but it is among the only histories written within the lifetimes of the veterans of the war.

The next major historical work on the Philippine-American War was Leon Wolff's Little Brown Brother: How the United States Purchased and Pacified the Philippine Islands at the Century's Turn. ${ }^{34}$ First published in 1961, Wolff's work was a more comprehensive study of the war, if still incomplete. Wolff painted the war in stark terms and even went so far as to declare it a "moral wrong." Sexton's works, the books ended before the war did; that is to say, they recount the war until Aguinaldo's capture. The events after that date, including Bell's campaign in Batangas, were not discussed at length but rather became mere epilogues.

A counter point to Wolff emerged in 1973 when John Gates authored Schoolbooks and Krags: The United States Army in the Philippines 1898-1902. ${ }^{36}$ Gates acknowledged the damage done to the Army's reputation and understood the popular image of the Army in the Philippines as one of widespread misconduct. His work argued for a different image of the Army, one of both military and humanitarian work during the conflict. Gates attributed America's successful pacification of the islands to the ability of American military and civil governors to win over Filipinos through public improvements as much as he credits American military action.

\footnotetext{
${ }^{34}$ Leon Wolff, Little Brown Brother: How the United States Purchased and Pacified the Philippine Islands at the Century's Turn (New York, N.Y.: History Book Club, 2006).

35 Ibid., 366.

${ }^{36}$ John M. Gates, Schoolbooks and Krags: The United States Army in the Philippines, 1898-1902, First Edition (Westport, Conn: Praeger, 1973).
} 
While not as broad as some areas of military history, secondary literature on the Philippine-American War was forthcoming. By the 1990s, authors began to write more focused works on the war. An example highly relevant to this thesis is Glenn May's Battle for Batangas: A Philippine Province at War, ${ }^{37}$ which he published in 1991. May did not cast his book as merely another military history. Instead, May's work studied the movement that opposed the Americans in that province.

May determined that the role of the U.S. Army in Batangas is somewhere between the benevolent peacekeepers and ruthless counter-insurgents previously portrayed, but that the Army ultimately still caused the civilian loss of life in Batangas. He argued that Bell's campaign compounded already serious food shortages and environmental factors that led to high numbers of civilian deaths. His study included a deeper examination of the Filipino resistance than many other works, although it was limited to one region, and concluded that local elites led the resistance. Once they realized the benefit to be gained from accepting American rule and saw the disastrous effects of further fighting, they worked within American rule rather than against it.

In more recent years, several authors have added to the literature on the Philippine-American War. Most notably, Brian Linn wrote two books: The Philippine War 1899-1902 ${ }^{38}$ and The U.S. Army and Counterinsurgency in the Philippine War, 1899-1902. ${ }^{39}$ Linn made a case for the Philippines not as a war of terror, but as a local

\footnotetext{
${ }^{37}$ Glenn Anthony May, Battle for Batangas: A Philippine Province at War, First Edition (New Haven: Yale University Press, 1991).

${ }^{38}$ Brian McAllister Linn, The Philippine War, 1899-1902 (Lawrence: University Press of Kansas, 2000).

${ }^{39}$ Brian McAllister Linn, The U.S. Army and Counterinsurgency in the Philippine War, 1899-1902, First Edition (Chapel Hill: The University of North Carolina Press, 2000).
} 
war that varied widely among villages, towns, and provinces throughout the Philippines. Linn added to the scholars arguing a case for the American military outperforming the Filipinos on the battlefield and balancing combat with social reform to win over Filipinos.

Worthy of mention, several of these books have drawn comparisons to counterinsurgency wars, including those in Vietnam, Afghanistan, and Iraq. Some books have even placed the Philippine-American War within the wider context of twentieth-century insurgency warfare like James Arnold's Jungle of Snakes: A Century of CounterInsurgency Warfare from the Philippines to Iraq. ${ }^{40}$ Even writers within the military began reassessing the Philippine-American War as the U.S. Army was engaged in two counter-insurgency wars during the 2000s. Two prime examples beings Lessons From a Successful Counterinsurgency: The Philippines, $1899-1902$ by Timothy Deady ${ }^{41}$ and All Wars are Local: Lessons From the Philippine Insurrection by Todd Brost. ${ }^{42}$

To compare the Philippine-American War with prior U.S. conflicts, historians need to look at works like Matthew Carr's Sherman's Ghosts: Soldiers, Civilians, and the American Way of War. ${ }^{43}$ Carr's book does not a directly examine the PhilippineAmerican War. Rather he relates Sherman's hard war to other American conflicts. Carr drew a link between the Civil War and the Philippine-American War. In another recent work, Max Boot wrote Savage Wars of Peace: Small Wars and the Rise of American

\footnotetext{
${ }^{40}$ James R. Arnold, Jungle of Snakes: A Century of Counterinsurgency Warfare from the Philippines to Iraq, First Edition (New York: Bloomsbury Press, 2009).

${ }^{41}$ Timothy K. Deady, "Lessons from a Successful Counterinsurgency: The Philippines, 1899-1902" (DTIC Document, 2005)

${ }^{42}$ Todd Brost, "All Wars Are Local: Lessons from the Philippine Insurrection" (DTIC Document, 2009).

${ }^{43}$ Carr, Sherman's Ghosts, 2015.
} 
Power ${ }^{44}$ in order to examine the ways that the smaller conflicts throughout our history have shaped the American way of war. Boot placed the Philippines in the context of conflicts like the Barbary Wars or American interventions in Central and South America. Ultimately the historiography of the Philippine-American war has centered on reexamining the U.S. Army's role in the conflict, and this thesis has much in common with that theme.

\footnotetext{
${ }^{44}$ Max Boot, The Savage Wars of Peace: Small Wars and the Rise of American Power, Revised Edition (New York: Basic Books, 2014).
} 


\section{CHAPTER 1: CONVENTIONAL WAR}

Early on the morning on May 1st, 1898 Commodore George Dewey ordered the captain of the USS Olympia to open fire on the Spanish fleet in Manila Bay in the Philippines. This naval battle sparked U.S. involvement in the Philippines for the next half century. On paper, the forces were roughly equal, seven ships to a side. The Spanish also had some supporting artillery on the island of Corregidor. However, the Spanish ships were obsolete and outgunned compared to Dewey's modern armored cruisers. The Spanish commander had recognized his low chances of victory and had placed his ships in shallow water in the hope of giving his sailors the opportunity to swim ashore. His fears proved well founded, as accurate American gunfire destroyed his fleet. The casualty list showed similar results, 371 Spanish casualties to nine American wounded and one American dead from heatstroke. Dewey's victory at Manila Bay turned him into a national hero and put America on a path to further involvement in the Philippines that would lead to the Philippine-American War the following year. ${ }^{45}$

The Spanish-American and Philippine-American Wars would open a new chapter in American military history. The major campaigns of the Plains Wars against Native Americans were over. For many soldiers and officers, the coming conflict would be an opportunity after years of career stagnation. For the country, it was a chance to step onto

\footnotetext{
${ }^{45}$ David J. Silbey, A War of Frontier and Empire: The Philippine-American War, 1899-1902, First Edition (New York: Hill and Wang, 2008), 37-39.
} 
the world's stage. For James Franklin Bell the Philippine-American War propelled his career from a circuit riding garrison lieutenant and teacher into a Medal of Honor recipient and, eventually, U.S. Army Chief of Staff.

Bell had been born in the town of Shelbyville, Kentucky in 1856, just a few years before the Civil War. He attended West Point and graduated in 1878, first posted to the 9th Cavalry Regiment and within months to the 7th Cavalry Regiment. He spent his years between graduation and his assignment to the Philippines in various stations in the Western United States. He spent time guarding railroads, teaching, serving as a judge advocate, and in garrisons from Arizona to South Dakota. ${ }^{46}$ Only a few pictures of Bell exist, but one is from his time as a lieutenant at Pine Ridge Indian Reservation with the 7th Cavalry Regiment taken in 1890, although Bell was on leave at the time of the Massacre of Wounded Knee. ${ }^{47}$ When the Spanish-American War broke out Bell received orders that attached him to General Wesley Merrit's command as a Major of Volunteers. Bell distinguished himself, and by the end of the Philippine-American War he would be one of the Army's most respected commanders and the archetype of an American officer during the period.

From the outset, American actions in the Philippines lacked direction as policy from Washington was either unclear or not communicated in time. Dewey had won a victory, but at least for a time, no one seemed sure what to do with it. War then erupted between the Filipinos and Americans before a well-defined American policy emerged -

\footnotetext{
46 “James Franklin Bell,” accessed December 30, 2016, http://www.history.army.mil/books/CG\&CSA/BellJF.htm.

47 “[Pine Ridge Officers] :: Historical Photograph Collection," accessed December 30, 2016, http://contentdm.lib.byu.edu/cdm/ref/collection/Camp/id/270.
} 
and it was really the U.S. Army and Navy which drove the Mckinley Administration's decisions about the islands and not the other way around. The initial successes by American forces also masked the formation of a Filipino guerrilla army that would soon fight an insurgency against the Americans until 1902.

Before American involvement in the Philippines, Filipinos had been in revolt against Spanish colonial rule. The Philippines of the 1880s and 1890s had suffered economic hardship, crop and livestock loss, and disease. These conditions created an environment for dissatisfaction and dissension. This cultural climate spawned a Filipino revolution in the mid-1890s against Spanish rule. The revolutionaries that emerged were groups that shared a common enemy but otherwise were split by longstanding class and ethnic divisions. The Tagalog people were one of the most influential ethnic groups of the revolution. One of their own, Emilio Aguinaldo, emerged as a leader that represented their interests in overthrowing Spanish rule but would keep the power among wealthy Filipino landowners. Another significant faction in the Filipino revolution was the Katipunan. This group consisted of farmers and merchants from the cities and was led by Andres Bonifacio.

The competition between these groups hindered the revolt, and by 1897 Spain had gained the upper hand. Emilio Aguinaldo demonstrated skill as a politician and was elected president of the revolutionary government. His ascension to leadership marked trouble for his rival Bonifacio. Aguinaldo ordered Bonifacio to be arrested on accusations of treason and executed him. Later Aguinaldo claimed that he, in fact, had commuted Bonifacio's death sentence, but that the order to stay the execution had not arrived in time. Despite Aguinaldo's clear leadership of the revolutionary forces, they 
still struggled to make gains against the Spanish. By August of 1897, the two sides began negotiations. These negotiations resulted in a treaty which ended the revolution in exchange for payment to the Filipino revolutionary leaders whom Spain exiled to Hong Kong. Neither side stayed faithful to its treaty obligations. The Spanish only paid half of what they promised, and Aguinaldo placed much of the money into a bank account to fund later revolutionary efforts. ${ }^{48}$

While Aguinaldo waited for a chance to resume his revolution in the Philippines, the Spanish-American War broke out on the other side of the world. This new war was the result of another revolt against Spanish rule. At the time, Cuba was one of the last Caribbean holdings of the dwindling Spanish empire. Cuban revolutionaries had proven more successful in their fight against Spain. In response to a more aggressive and effective insurgency in Cuba, the Spanish responded with stringent measures. The governor of Cuba was Valeriano Weyler, and among the policies that he implemented to quell the revolt was one known as Reconcentrado. ${ }^{49}$

Under this policy, Cuban civilians were forcibly moved by the Spanish military into zones that the Spanish controlled. Spanish officials were unable to keep a steady food supply to these areas which led to malnourishment and starvation. Weyler's Reconcentrado caused considerable outrage in the United States. In the winter of 190102, as a General, James Franklin Bell instated a similar policy to combat the Filipino insurgency, anti-imperialists decried his policies as "Weylerism.",50

\footnotetext{
${ }^{48}$ Silbey, A War of Frontier and Empire, 2008, 10-16.

${ }^{49}$ Ibid., 30-32.

${ }^{50}$ Brian McAllister Linn, The Philippine War, 1899-1902 (Lawrence: University Press of Kansas, 2000), 302 .
} 
Weyler's policies led to a diplomatic intervention by the United States. Spain recalled Weyler, and President McKinley offered to oversee peace negotiations between the Cuban revolutionaries and the Spanish. In the meantime, President McKinley dispatched the USS Maine to Havana to protect American interests in the city. On February 15, 1898, the Maine exploded and sunk. The explosion killed 266 of the 350 men onboard. The sinking pushed existing tensions to the brink and stirred war sentiment in the United States. ${ }^{51}$

The cause of the explosion that sank the Maine was not immediately clear, and President McKinley ordered an investigation that became known as the Sampson Board. On March 21, 1898, the board concluded that the cause of the explosion had been a mine that had detonated the ship's magazines. The board's investigation ignored a report from January of that year that had warned of the risk of a fire in the coal bunker detonating a ship's magazine. Studies since the explosion have placed serious doubt on the Sampson Board's findings, most notably, a study by Admiral Hyman Rickover in 1974.

Regardless of its accuracy and lack of a named culprit the Sampson Board's finding of the external explosion was enough to push the U.S. Congress into demanding a Spanish withdrawal from Cuba, and allowing the use of force if they did not. ${ }^{52}$

When America declared war in the spring of 1898 the country possessed only limited military capabilities. At the end of the Civil War, the United States Army and Navy stood among the largest in the world. The ranks of both services swelled because

\footnotetext{
${ }^{51}$ Leon Wolff, Little Brown Brother: How the United States Purchased and Pacified the Philippine Islands at the Century's Turn (New York, N.Y.: History Book Club, 2006), 37-42.

${ }^{52}$ Louis Fisher, "Destruction of the Main (1898)," 1-4, accessed March 29, 2016, https://www.loc.gov/law/help/usconlaw/pdf/Maine.1898.pdf.
} 
of the emergency of the Civil War. Once it was over, both demobilized down to prewar levels even more quickly than they had grown. The Army reduced its strength to barely enough manpower to patrol the frontier and enforce reconstruction. The Navy reverted to sail power to carry out its largely diplomatic functions. This drastic reduction frustrated those within the military, but it fit the needs of the country.

American strategy reverted, along with its manpower levels, to pre-Civil War doctrine of relying on coastal fortifications and the expanse of the Atlantic and Pacific Oceans to protect the country. For much of the remainder of the nineteenth-century American military thinking looked to the problem of defending its shores. Even as late as 1898 Army writings focused on hypothetical invasions that would require a major land force to defeat them, instead of the wars that they were about fight. ${ }^{53}$

The United States had few enemies, and only Britain or France had the capability of sending an invasion force to America. With limited budgets that reflected the lack of external threats, the military languished. In the 1880s things began to reverse course, albeit slowly. The Navy began receiving appropriations from Congress to build new steel warships and start the process of catching up on twenty years' worth of naval innovation. The resulting ships and modern guns they mounted would be the vessels that carried out the destruction of the Spanish fleet in $1898 .^{54}$

The Army especially found itself unprepared for an overseas conflict. At the height of the Civil War, over a million men were enlisted in the U.S. Army. By 1875 that

\footnotetext{
${ }^{53}$ Linn, The Echo of Battle, 55.

${ }^{54}$ Russell F. Weigley, The American Way of War: A History of United States Military Strategy and Policy, (Bloomington: Indiana University Press, 1977), 167-169.
} 
number had dropped to 25,000 . Life in the army was short on pay and chances for promotion, and the men that enlisted often had few other options. As many as one in seven deserted each year. Pay for a private in the 1870s had dropped from thirteen dollars a month to ten. Recruits received poor training and uniforms and often lived in marginal conditions. ${ }^{55}$ Officers of the era spent decades at the same rank. Arthur MacArthur, later to command U.S. forces in the Philippines, achieved the rank of Lieutenant Colonel during the Civil War. Afterward, he spent 23 years as a captain. ${ }^{56}$

This small frontier garrison force was the army that James Franklin Bell had joined in the 1870s. Bell spent his first twelve years in the Army as a 2nd Lieutenant and was not promoted to Captain until the Spanish-American War. Despite his long service, Bell still managed to be the junior of many Army officers. Shortly before the SpanishAmerican War began, the Army reported that 271 of its captains and lieutenants had fought in the Civil War. When war broke out with Spain over 100,000 Civil War veterans volunteered to fight. This volunteerism included ex-Confederate Generals Joseph Wheeler and Fitzhugh Lee who were each appointed to commands in the newly raised volunteers. A reporter favorably described the men of the army as "Generally stalwart, sunburnt, resolute-looking men, twenty-five to thirty-five years of age, who seemed to be in perfect physical condition, and who looked as if they had already seen hard service and were ready and anxious for more. ${ }^{.57}$ The description proved accurate, at least in part, since only 40 soldiers in the regular army in the spring of 1898 were under

\footnotetext{
${ }^{55}$ Cozzens, The Earth Is Weeping, 54-56.

${ }^{56}$ Silbey, $A$ War of Frontier and Empire, 2008, 17-18.

${ }^{57}$ Edward M. Coffman, The Regulars: The American Army, 1898-1941 (Cambridge, Mass.; London: Belknap Press, 2007), 9.
} 
the age of 21, and a third of all enlisted men had been in the Army for more than five years. $^{58}$

The war in the Philippines shared much with the Plains Wars that the Army had been fighting until that point. Both saw the Army deployed to remote garrisons that were manned by a small unit. In the Philippines, these posts were often manned by a company or less. In both, the Army faced opponents that could be difficult to bring to battle and could melt away into difficult or vast terrain. The Army would turn to forced relocation and indirect attacks on the enemy's means to wage war to overcome these problems in each conflict. A way of war that Secretary of War John Floyd explained as, "beating their forces, capturing many prisoners...destroying large amount of property, and laying waste to their country." ${ }^{, 59}$ Floyd made his statement in 1858 to describe the way the Army had been fighting Native Americans on the frontier. A way of war which had frustrated many officers who focused on wars against western nations instead of the colonial style of warfare that had occupied the Army until that point. ${ }^{60}$

The Plains Wars and the Philippine-American War also shared social characteristics. American soldiers faced isolation, frustration, and poor pay. Their opponents were non-whites and soldiers often harbored racial prejudices towards their enemies. The similarities of frontier duty in the American West and the PhilippineAmerican War, combined with the shift towards a reformed industrialized army in the

58 Ibid, 9.

${ }^{59}$ Linn, The Echo of Battle, 70.

${ }^{60}$ Ibid., 69-70. 
early 1900s, meant that the Philippine-American War would be the last major conflict of the frontier Army. ${ }^{61}$

Despite the problems the Army faced, however, it brought strengths to the conflict that it had not anticipated and was not prepared to fight. By the time the PhilippineAmerican War broke out, the long-serving veterans of the Army had begun to see some efforts at modernization, even if it was happening slowly. During the 1870 s and 80 s, the Army had adopted new modern breech-loading artillery, including easily transportable mountain guns. Small arms and infantry tactics underwent changes as well. In the early 1890s, the army switched from single-shot black powder rifles to magazine fed smokeless powder rifles. However, many of the volunteer units still carried the older weapons well into the war. Regulars and volunteers benefited from a new tactical manual issued in 1891 that emphasized open order, supporting fire, and advancing while using cover and short rushes. While many of these changes were brought about in response to similar changes in European armies, they faced their first trial in the Philippines. $^{62}$

\section{FROM SPANISH-AMERICAN TO PHILIPPINE-AMERICAN WAR}

The official declaration of war against Spain came on April $25^{\text {th }} 1898$ following an investigation into the cause of the USS Maine explosion. The Philippines were not the immediate concern of most Americans, save for a few members of the Naval Department, including Assistant Secretary of the Navy, Theodore Roosevelt. Roosevelt ordered the

\footnotetext{
${ }^{61}$ Brian McAllister Linn, “The Long Twilight of the Frontier Army,” The Western Historical Quarterly 27, no. 2 (1996): 141-67, doi:10.2307/970615.

${ }^{62}$ Linn, The Philippine War, 1899-1902, 2000, 8-9.
} 
American squadron under Dewey to the Philippines. Based on prewar plans to attack the Spanish Pacific Fleet, Roosevelt ordered Dewey to prepare to attack the Spanish at Manila. Roosevelt's orders to Dewey, among others, caused the Secretary of the Navy, John Long, to worry that Roosevelt had done more to bring about war than the sinking of the Maine, but Long did not countermand them. The eventual outcome of the battle of Manila Bay would be entirely one-sided, but while the American squadron readied itself in Hong Kong, observers there speculated on its defeat at the hand of well-prepared Spanish defenses, including mines and shore batteries, concerns eventually proven to be unfounded. ${ }^{63}$

While Dewey readied his squadron for war, Aguinaldo began his preparations to resume leadership of the insurgency against Spain. Dewey's victory created a problem for McKinley who was unsure what to do in the Philippines. In the meantime Filipinos had already begun to fight against the Spanish once again, assuming that they would receive American support for their cause. Under local commanders, Filipino forces gained control of much of the Philippines and besieged Manila. Although initially effective, this regional loyalty would later cause problems for the Filipino Army of Liberation. $^{64}$

Meanwhile, Aguinaldo was in communication with the American consulate in Singapore. The meetings there became a source of controversy almost immediately. Aguinaldo claimed that he had been promised American support for Filipino

\footnotetext{
${ }^{63}$ Wolff, Little Brown Brother, 2006, 45-55.

${ }^{64}$ Max Boot, The Savage Wars of Peace: Small Wars and the Rise of American Power, Revised Edition (New York: Basic Books, 2014), 104.
} 
independence and self-rule. American officials denied having ever promised that to Aguinaldo, but Dewey did give him military supplies, including rifles and orders for U.S. agents to purchase more in Hong Kong. Aguinaldo used money which had been on hand since Spain's payment years earlier to order 2,000 modern Mauser rifles, along with 200,000 rounds of ammunitions for just over $\$ 20,000$. He provided nearly $\$ 70,000$ more to buy up additional munitions and supplies for the Revolutionary Army. ${ }^{65}$ The U.S. may have come to regret facilitating these arms purchases as capturing arms later became a primary objective for U.S. commanders fighting the Filipinos. With these weapons and aid from the U.S., Aguinaldo began organizing a Filipino government and army to wage war against the Spanish. ${ }^{66}$

Officially Dewey's objective had been to prevent the Spanish fleet from attacking the American West Coast, but realistically the lopsided victory at Manila Bay had achieved much more. The Philippines were on the table now as a possible territorial gain, instead of just Cuba. Initially, McKinley did not create an official stance about taking the Philippines from Spain, but he did order the War Department to send troops. As effective as the American Navy was against the Spanish, it was not equipped to seize any territory. The first 2,500 troops departed on May 25th. On the way, these forces sailed to Guam, and on their arrival, the Spanish commander met them in a small boat to apologize that he had no cannon to offer a salute, unaware of the war since word of

\footnotetext{
${ }^{65}$ Wolff, Little Brown Brother, 2006, 50-51.

${ }^{66}$ Silbey, A War of Frontier and Empire, 2008, 36-43.
} 
hostilities had not reached the island. More troops left for the Philippines in June, 3500 on the 15 th and 4800 on the 27 th. ${ }^{67}$

The American soldiers arrived in Manila to find an unusual three party siege of the city. The Spanish held Manila with a garrison of approximately 15,000 men. Aguinaldo had surrounded the city on land with a roughly equivalent number of his own troops. The Filipino army was weakened by Aguinaldo's decision to send additional forces to aid in the war in the provinces and was unable to breach the Spanish defenses. Dewey maintained a naval blockade of the city, and the American army landed at Cavite, near Manila, but did not take a place in the trenches alongside the Filipino Army of Liberation. Officers within the American 8th Corps had to negotiate to take over a portion of the Filipino lines next to the shoreline on the south side of Manila, next to the bay and the American naval guns floating offshore. While the American command, including 8th Corps intelligence officer James Franklin Bell, unsuccessfully searched for a weak point in the Spanish lines to their front, the American soldiers lived in wet trenches under fire from Spanish sharpshooters. ${ }^{68}$

Unfortunately for the Americans, there seemed to be no way to take the Spanish defenses other than a frontal assault. Behind their lines, the Spanish colonial authorities had their own worries, most important their fear of what would happen if the Filipinos took the city and the 70,000 residents still living there. The Spanish colonial government did not want to surrender to the Filipino forces, and the Spanish government did not want its commander to surrender at all. When the governor general suggested capitulation, he

\footnotetext{
${ }^{67}$ Ibid., 43-45.

${ }^{68}$ Linn, The Philippine War, 1899-1902, 2000, 24-25.
} 
was sacked and replaced, but the new governor general agreed with his predecessor. With help from the Belgian Consulate, he secretly negotiated an agreement with the Americans that as long as the American Navy did not shell the city, then the Spanish batteries would not open fire. Dewey believed that the Spanish only planned to offer token resistance, Merritt did not agree. He felt that it only applied to the naval engagement, and kept the information from his officers. ${ }^{69}$

On August $13^{\text {th }}, 1898$, the Americans launched an attack during a rainstorm. Dewey's ships provided a bombardment of Spanish strongpoints while 8th Corps infantry advanced on the Spanish positions. Whatever the understanding was between the two sides before the attack, Dewey's understanding was the one that played out. Spanish defenders quickly retreated into the city and raised a white flag. American soldiers moved into the walled city to disarm the garrison and keep the Filipinos from entering. ${ }^{70}$

The American success of capturing Manila again highlighted the uncertainty in American policy about what to do with the Philippines. Following American victories in Cuba and the Philippines, Spain was eager to end the war before its losses started affecting domestic politics. American concerns at home were centered on what to do with the islands during a congressional election year, fresh off military victories, and while war and expansionist sentiment were still high. From the American perspective, Spain could not be allowed to keep the Philippines; there had been too much publicity of Spain's cruelty towards its colonial possessions.

\footnotetext{
${ }^{69}$ Ibid., 24.

${ }^{70}$ Silbey, A War of Frontier and Empire, 2008, 47-49.
} 
Letting the Filipinos gain control of the islands was never really an option either. The ideology of the day did not see them as fit for self-rule, and the U.S. desired a base in the Pacific that could give them influence and strategic access to Asia, especially China. The McKinley Administration assumed that to give control over to the Filipinos would result in another European power taking control of the islands. A squadron of German warships as strong as Dewey's had been shadowing the American Pacific Squadron and had even sailed into Manila Bay and landed onshore. At one point an American warship fired a warning shot at one of the German ships, and Dewy fumed at a German diplomat in a widely-reported encounter that only fueled speculation of European expansion. ${ }^{71}$ European interest in China and other Asian countries made it seem like a plausible outcome. America had seized part of the Philippines and could not give it up, and to take part meant it had to occupy the rest. McKinley perceived that other outcomes would not be acceptable to American voters faced with an upcoming election, or within his administration, that was worried about rival powers in the Pacific. ${ }^{72}$

The U.S. went to the negotiating table with Spain and demanded all of the Philippines. Spain held a weak position, both strategically and politically at home. Faced with American demands, Spain did not receive help from other European powers to try and curb America's gains. To other European powers, it was better to let the Americans get the remnants of Spain's colonies than to see it go to another rival. Without anything to bargain with or allies to help temper American demands, Spain gave the Americans what they wanted. America received Cuba, Puerto Rico, Guam, and, in exchange for \$20

\footnotetext{
${ }^{71}$ Wolff, Little Brown Brother, 2006, 114-15.

${ }^{72}$ Boot, The Savage Wars of Peace, 2014, 105-6.
} 
million, the whole of the Philippines. The two countries signed the Treaty of Paris on December 10th, 1898, just under eight months from the outbreak of the war and less than a year since the sinking of the Maine. ${ }^{73}$

Between the capture of Manila in August and the treaty in December, American, and Filipino forces had tenuously remained in place. Aguinaldo's forces were still receiving regular supplies of weapons from Hong Kong. ${ }^{74}$ The Americans held the city and denied entry to the Army of Liberation which remained entrenched around the Manila. James Franklin Bell, who had been assigned to Merritt's command as a Major of Volunteers, helped ease this situation somewhat by functioning as a negotiator. The truce held, but a new American commander made matters worse. General Elwell Otis replaced Merritt when Merritt was sent to France to help negotiate an end to the Spanish-American War. Otis had been in the Army for more than thirty years when the Spanish-American War began. He had fought on Little Round Top during the Battle of Gettysburg with the 140th New York and continued fighting for the Union until he was wounded in the head during the Siege of Petersburg. During his tenure in the Philippines, he became deeply unpopular with the American volunteers. "Granny" Otis, as soldiers called him, was criticized by his contemporaries for his temperament, inability to delegate, and overreaching attention to detail. He allegedly once went to verify the value on a dead mule. $^{75}$

\footnotetext{
${ }^{73}$ Silbey, A War of Frontier and Empire, 2008, 57-58.

${ }^{74}$ Wolff, Little Brown Brother, 2006, 138-39.

${ }^{75}$ Ibid., 141.
} 
Otis' faults exacerbated a tense situation that neither Otis nor Merritt were wellequipped to handle. Conditions in Manila were unpleasant and unsanitary, Filipino soldiers could enter the city unarmed, but would later face off against American soldiers along the lines outside the walled city, and neither commander was able to get clear instructions from the McKinley Administration. ${ }^{76}$

Otis quickly issued a letter to Aguinaldo that demanded the withdrawal of the Army of Liberation. Unsurprisingly, Aguinaldo kept his army in place. The tension between leaders was matched by tension between soldiers. Patrols and sentries faced each other day after day, and disputes, including gunfire, had to be settled before they turned into an all-out battle.

News of the peace treaty reached the Philippines in January 1899 and only made tensions worse. From the Filipino standpoint, the treaty represented a second betrayal following American seizure of Manila. Aguinaldo issued a proclamation that denounced the treaty and warned of bloodshed. He also began to plan for war and started organizing forces within the city to take part in an uprising once the fighting began. If the Filipinos could coordinate their efforts, then American forces stretched thinly along the perimeter of Manila would have to deal with hostile forces from two directions. The treaty removed any remaining pretense of a peaceful solution to the ongoing standoff and drove home the possibility that any spark could be the one to bring about war. ${ }^{77}$

The personal and military tensions were exacerbated by a clash of cultures. American attitudes towards Filipinos, both combatants and non-combatants, were

\footnotetext{
${ }^{76}$ Linn, The Philippine War, 1899-1902, 2000, 26-27.

${ }^{77}$ Silbey, A War of Frontier and Empire, 2008, 59-64.
} 
thoroughly racist. The language that American soldiers used to describe Filipinos was often filled with the same racial slurs and epithets that were in use towards Native and African-Americans. Even the soldiers and officers that saw some noble purpose in America's incursion into the Philippines often spoke of Filipinos as an inferior race. To them, it was because of the Filipino's inability to rule themselves that the Americans were there in the first place. McKinley, Taft, Bell, and other figures all espoused this idea at one point. Even reporters that discussed the harsh counter-insurgency campaign that Bell led listed the excesses of violence enacted by American soldiers, but went on to declare that the Filipinos were savages that only responded to violence. ${ }^{78}$

At the time, there were voices of dissension, both in the Army and back in the United States, Mark Twain being one of the most famous. ${ }^{79}$ One of the apocryphal stories about the Philippine-American War that highlights the complicated and derogatory nature of the war comes from the arrival of the African-American 25th Infantry Regiment. When asked by a white soldier what they were doing there, a trooper from the $25^{\text {th }}$ Infantry Regiment is reported to have replied that they were there to "Take up the white man's burden" referencing Rudyard Kipling's poem about the PhilippineAmerican War. ${ }^{80}$ But despite some limited dissent, American troops largely thought of the Filipinos as "other." Whether the view was based in a paternal racism that thought of

\footnotetext{
${ }^{78}$ Gregg Jones, Honor in the Dust: Theodore Roosevelt, War in the Philippines, and the Rise and Fall of America's Imperial Dream, First Edition (New York: NAL, 2012), 95-98.

${ }^{79}$ Stanley Karnow, In Our Image: America's Empire in the Philippines, 1989, 82.

${ }^{80}$ David J. Silbey, A War of Frontier and Empire: The Philippine-American War, 1899-1902, First Edition (New York: Hill and Wang, 2008), 107.
} 
Filipinos as a society that needed American governance or outright racism that saw Filipinos as savages, American troops viewed and treated their enemy as an inferior race.

On February $4^{\text {th }} 1899$, tensions that had been building for months spilled over. Sometime around 8:30 that evening, three soldiers from 1st Nebraska Volunteer Infantry Regiment were on patrol at a vulnerable point in the American line, close to one of the former Spanish blockhouses. The American defense was stretched thin around Manila, most regiments covered their assigned areas with outposts and picket lines, with regular patrols to cover the gaps. At this particular point in the line, tensions were already high, as the Nebraskan volunteers held a particularly exposed position that just days before had been the subject of a dispute about the neutral zone between the two armies. What led to the firing is still debated, some sources claiming that the Filipinos were peacefully guarding their outpost, while others maintain that they approached the American patrol and refused to halt. Many Filipino sources assert that Cpl. Anastascio Felix, along with two other soldiers were standing in the doorway to Blockhouse Number 7, one of the former Spanish positions, when Americans shot them. ${ }^{81}$

Regardless of the cause, what is generally agreed on is that Pvt. William Grayson fired the first shot that killed one of the Filipinos, followed in quick succession by two more shots from Grayson's companions. Grayson offered his own account of what happened that evening.

"I challenged with another "Halt." Then he immediately shouted "Halto" to me. Well I thought the best thing to do was to shoot him. He dropped. Then two Filipinos sprang out of the gateway about fifteen feet from us. I called "Halt" and Miller fired and dropped one. I saw that another was left.

\footnotetext{
${ }^{81}$ Linn, The Philippine War, 1899-1902, 2000, 46.
} 
Well I think I got my second Filipino that time. We retreated to where six other fellows were and I said "Line up fellows; the niggers are here all through these yards." 82

As Grayson and his fellow Nebraskans ran back to their lines, firing spread to the rest of their unit, and soon spread to neighboring units and beyond until the entire perimeter was engaged in a sporadic firefight through most of the night. Several American units reported heavy firing along with probing attacks on their positions. Sentries had fired on each other before, and there was little love among American soldiers for their Filipino counterparts. By this point, both the Americans and Filipinos expected and were planning for a war when the firing started. This time around there was no one in a position to stop it. ${ }^{83}$

By the next morning, the firefight evolved into a general engagement all around the city. The American Provost Guard in Manila proper quickly cracked down on suspected insurgents, and although a few managed to snipe or start fires, the feared twopronged attack never emerged, partly thanks to quick action on the part of the Americans, but mainly because the battle had taken the Filipinos by surprise as well. Those who had been preparing an attack from within the city were not ready to act when the fighting began. $^{84}$

Along the perimeter, the 8 th Corps was divided into two divisions, the 1 st under General Thomas Anderson defending the south side of the city, and the 2nd under General Arthur MacArthur defending the northern side. Both commanders had

\footnotetext{
${ }^{82}$ Stuart Creighton Miller, Benevolent Assimilation: The American Conquest of the Philippines, 1899-1903, Reprint Edition (New Haven: Yale University Press, 1984), 61.

${ }^{83}$ Ibid., 58-63.

${ }^{84}$ Linn, The Philippine War, 1899-1902, 2000, 45-51.
} 
developed contingency plans in case of an outbreak of hostilities, and began to put their plans in motion with support from warships in the harbor and the Navy's gunboats in the Pasig River. All along the line, American regiments launched attacks that drove back the Filipinos and captured their defenses. Eager volunteers alongside the stalwart regulars made use of reformed tactics they had learned in the months since they had enlisted. They advanced in short rushes, using their own volleys of rifle fire and supporting artillery to cover their advance. While there was some confusion and strong resistance at points, by the end of the day the Americans had soundly defeated the Army of

\section{Liberation. $^{85}$}

The Battle of Manila became the largest battle of the Philippine-American War, between 11,000 American soldiers, and maybe as many as 20,000 Filipinos. American casualties amounted to 44 killed and 194 wounded. Filipino losses are harder to determine; some estimates placed the number in the thousands. ${ }^{86}$ One source places Filipino dead, not including wounded, at 3,000. ${ }^{87}$ The official American report claimed the Filipinos had suffered 700 killed and 3,300 wounded. ${ }^{88}$ Otis speculated that there had been about 500 Filipinos killed and another 500 captured, and while his own casualties were light in comparison, they were enough to give him pause, considering how thinly stretched his lines were. ${ }^{89}$

\footnotetext{
${ }^{85}$ Ibid., 49-52.

${ }^{86}$ Silbey, A War of Frontier and Empire, 2008, 71.

${ }^{87}$ Miller, Benevolent Assimilation, 68.

${ }^{88}$ Linn, The Philippine War, 1899-1902, 2000, 52.

89 John M. Gates, Schoolbooks and Krags: The United States Army in the Philippines, 1898-1902, First Edition (Westport, Conn: Praeger, 1973), 77.
} 


\section{PROBLEMS WITHIN THE ARMY OF LIBERATION}

The Philippine-American War began on the evening of February 4th, 1899. For much of 1899, the war was waged between two standing armies. By year's end, however, Aguinaldo shifted into a guerrilla war after failing to hold the Americans in Manila. During the conventional phase of the war, Filipino forces struggled to defend even strong positions. They could hold the Americans and inflict losses, but American soldiers often easily breached positions that should have been formidable. Before the Battle of Manila, Filipinos had worked for months preparing their positions, and all the wisdom of the day spoke to the difficulty in taking prepared positions, even those defended in small numbers. As the campaign went on American soldiers and officers showed aggression, and even assaults against larger forces often succeeded, typically with light casualties. ${ }^{90}$

In fact, Americans soldiers had even recently experienced the potential cost of attacking an entrenched enemy. At the battle of San Juan Hill the previous summer, Americans had attacked Spanish forces who were dug in and equipped with modern rifles. Although the battle was a victory for the Americans they suffered heavy casualties, 210 killed and 1,180 wounded. The Spanish suffered significantly fewer casualties, 215 killed, and only 376 wounded. In that battle, they had been attacking a smaller Spanish force, less than 2,000 strong. ${ }^{91}$

\footnotetext{
${ }^{90}$ Silbey, A War of Frontier and Empire, 2008, 70-72.

${ }^{91}$ Gregg Jones, Honor in the Dust: Theodore Roosevelt, War in the Philippines, and the Rise and Fall of America's Imperial Dream, First Edition (New York: NAL, 2012), 77.
} 
At a glance, the differences in the experience of the soldiers does not seem to be the answer. The American troops at this early stage of the campaign mostly consisted of state volunteers with mixed levels of training. Filipino forces consisted of men with experience fighting the Spanish, ex-members of Spanish colonial militias, and new recruits that by the time of open hostilities had been in the military as long as many of the American volunteers.

If experience was not the answer, then neither were the arms the two sides carried. Later in the war, and especially during the irregular phase of the war, American troops consistently used modern bolt action rifles while the Filipinos struggled even to keep their troops armed with any rifle. However, at this point, both sides carried a similar mix of small arms. Most of the volunteer units still carried single shot black powder arms. Thanks to the modernization efforts of the early 1890s, the Army had adopted a new magazine fed, bolt action rifle that used smokeless powder ammunition. The new KragJorgensen rifle incorporated features at the forefront of small arms technology of that era. However, government arsenals had not built enough of the new rifles yet to equip everyone. Regular units carried the new rifles while volunteers carried the older guns, only occasionally getting updated replacements. ${ }^{92}$

The weapons of the Filipino forces were as mixed as what the Americans carried. Although significant parts of the Filipino forces only had Bolo knives, many carried rifles. Until the beginning of the Philippine-American War in February 1899, the Filipinos had been able to bring in arms from outside and use what they had captured

\footnotetext{
${ }^{92}$ Silbey, A War of Frontier and Empire, 2008, 73-74.
} 
from the Spanish. When Dewey first arrived he had helped Aguinaldo purchase arms. The American Army only began their campaign to deny rifles to Filipino forces later. Filipino forces carried Mauser rifles, the most modern design in the world at the time, and American-made Remington Rolling Block rifles, another single-shot breechloader equivalent to the single-shot Springfield rifle that American volunteers used. These were the same kind of arms that the Spanish troops at San Juan used to inflict heavy losses on the American assault.

The largest differences in weapons between the two armies were artillery and ammunition supply. The Americans had modern artillery and, in some areas, supportive naval gunfire. Filipino forces had a few field guns, but that was all. The Filipino ammunition supply consisted of imported, captured, or locally produced ammunition. Often it was poor quality since it was hard to source the right components. Still, the Army of Liberation possessed modern weapons but failed to inflict heavy casualties. ${ }^{93}$

David Silbey argues that the overall poor performance of Filipinos was in the way they recruited and organized their troops. Deficiencies in training and equipment only provide part of the answer. Silbey points out that the Filipino forces were recruited at a local level often at a patron/client type relationship. Aguinaldo only had loose control over many of his commanders and could not enforce Army-wide standards of discipline.

During combat, this problem manifested itself as units fighting long enough to fill an obligation and then withdrawing, in some cases even before American troops had closed within effective range. Add to this the other problems with the Filipino combat

\footnotetext{
${ }^{93}$ Ibid., 72-73.
} 
abilities and American forces achieved victories that simply would not have been possible against other forces. Many Filipinos simply viewed war differently than their American counterparts. They filled their obligations by going out and firing at Americans until they felt threatened and then retreated, having done the extent of their duty. Limited firing at troops in the distance, combined with poor ammunition and training meant that Americans suffered much lighter casualties than an observer might have expected. Once troops fell back, they left gaps in the lines which American troops could exploit. ${ }^{94}$

Silbey's argument does provide an explanation beyond poor weapons or American individual soldier superiority. Withdrawing during combat is a risky undertaking for any force, but especially an undertrained one. In the face of a determined enemy it can be disastrous, as many of the Filipino defeats were. Brian Linn war argues along similar lines. He points out that while the weapons, training, and marksmanship all contributed to American success, the key factor was overall cohesion. While individual Filipino units fought well, they often did not rely on the units alongside them. This kind of breakdown could turn almost any break in the line into a chance for Americans to turn the battle. The Battle of Manila demonstrated the otherwise unproven capabilities of the American volunteers, while severely damaging Filipino morale. It also influenced the Americans to be highly aggressive throughout the war, even to the point of recklessness. ${ }^{95}$

During the conventional phase of the war, only a handful of actions resulted in anything close to significant American casualties. Most American attacks were one-sided

\footnotetext{
${ }^{94}$ Ibid., 72-76.

${ }^{95}$ Linn, The Philippine War, 1899-1902, 2000, 62-63.
} 
successes. American commanders learned to press the attack and their aggression paid off. They consistently drove the Army of Liberation back. Constant retreat never allowed the Filipinos a chance to institute any reform or spend the time that they needed to rest and improve.

For their credit, Filipino troops could stand and fight; the problem was which units could be counted on to fight and which could not. U.S. General Henry Lawton called the Filipino soldiers "The bravest men I have ever seen." ${ }^{96}$ Courage alone could not make up for the widespread deficiencies in the Army of Liberation. At least some Filipino officers recognized the problems, but trying to reform an army on limited resources in the face of an aggressive enemy was always going to be almost impossible, and Aguinaldo, though a shrewd politician, performed poorly as a military commander. ${ }^{97}$

During February 1899 Otis sought to maintain his position around Manila. Although American troops had been successful in the initial battles, their lines were thin, and Otis felt that he needed more manpower to go on the offensive without risking Manila. The Filipinos gave him good reason to worry as well. The previously discussed problems with the Army of Liberation were not entirely evident to the Americans yet, and it managed to keep the pressure on the American defenses. On February 22, 1899, they launched an attack on the city's northern suburbs after infiltrating American lines with approximately 1,000 men. The Americans repulsed the attack and inflicted heavy casualties on the Filipinos, but it was enough to remind the Americans that their lines

\footnotetext{
${ }^{96}$ Boot, The Savage Wars of Peace, 2014, 108.

${ }^{97}$ Silbey, A War of Frontier and Empire, 2008, 81-82.
} 
were vulnerable. To counter this threat, the Americans patrolled aggressively to break up any insurgent build up near the lines.

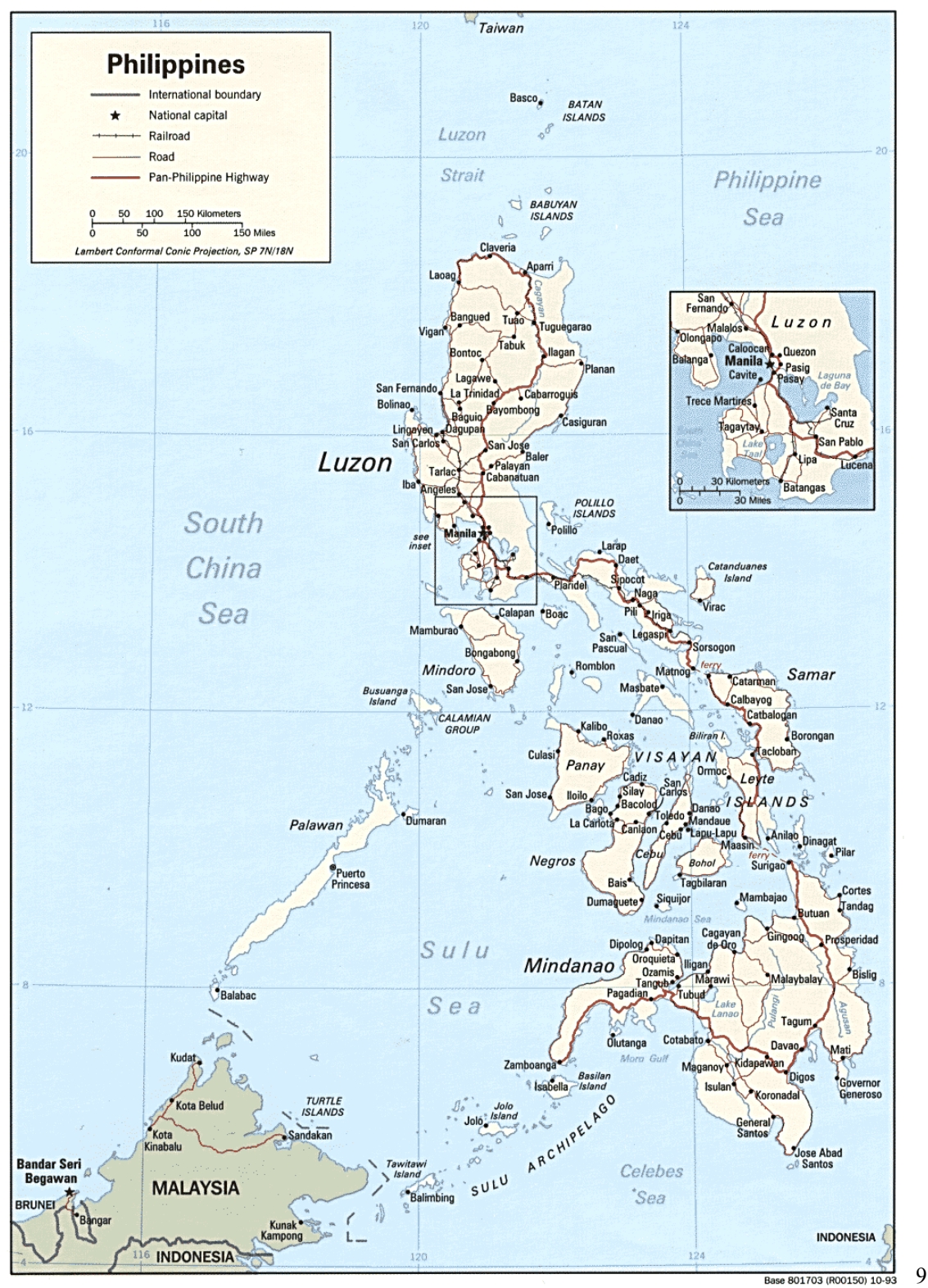

\footnotetext{
98 "Philippines Maps - Perry-Castañeda Map Collection - UT Library Online," http://www.lib.utexas.edu/maps/philippines.html.
} 


\section{AGUINALDO'S DEFEAT}

Otis soon began a two-pronged offensive from his base in Manila. MacArthur was to drive north toward the Filipino capital in Malolos with his division while General Anderson drove south with his division. The colorful Brigadier General Lloyd Wheaton led Anderson's spearhead. Wheaton was another Civil War veteran. He had enlisted during the war and eventually won the Medal of Honor and a promotion to brevet Colonel. Following the war, he reverted to the rank of Captain which he held for 25 years. He sought to move down the Pasig River and seize the fertile farmland around the lake Laguna de Bay. Wheaton's campaign began on March 12, 1899. His troops advanced along the Pasig River with help from the gunboat Laguna de Bay named after the lake that was their objective. Wheaton's troops encountered stubborn Filipino resistance, holding the Americans for several hours at a time. The Filipinos fought until they were threatened with being cut off or until the gunboat arrived with its heavy firepower. Despite this resistance, they were unable to stop Wheaton's column. The Americans achieved the objective, and along the way, Wheaton implemented a policy reminiscent of his former superior, General Sherman. Wheaton ordered the destruction of towns and villages along his line of advance, later claiming it was in response to enemy resistance. American soldiers burned buildings out to five miles on either side of the road as they marched, and as one soldier stated, "The entire district so destroyed so that it would seem necessary not only for a bird but even a Filipino to carry his rations while crossing it."99

\footnotetext{
${ }^{99}$ Linn, The Philippine War, 1899-1902, 2000, 94-95.
} 
MacArthur, who had expected heavy resistance, entered Malolos on March 31, 1899, and found only sporadic resistance in the city. MacArthur's command had suffered 56 killed and 478 wounded since early March. While these are not insignificant numbers, they were not enough to slow down or stop the American advance. Taking Malolos proved indecisive as Aguinaldo and the government retreated further. Observers began to note the difficulties in fighting the Filipinos, as a correspondent wrote about the objective, "[The Filipinos]...took up the goalposts and carried them back."100

The Army of Liberation retreated, along with the government, to Calumpit, a few miles to the north. MacArthur wanted to continue the advance, but Otis ordered him to stop and refit his troops before continuing. The American advance resumed on April 24, 1899. To defend the city General Luna dug in his troops behind a river, but even a strong natural defense and entrenchments did not stop the American assault. By April 25, 1899 the Americans captured Calumpit. American aggression, even against superior numbers and prepared positions, proved enough to rout Filipino defenders. As one soldier wrote home in early May "The new method of fighting this war is to fire a few rounds - then advance towards the enemy - firing as we go. using this tactic, the Filipinos cannot shoot at us without exposing themselves - which they seldom do - and they soon leave in a hurry."101

While troops fought in the Philippines, politicians had yet to ratify the Treaty of Paris, which had granted control of the Philippines to the U.S. Ratification was not a

\footnotetext{
${ }^{100}$ Stanley Karnow, In Our Image: America's Empire in the Philippines. New York, Random House, 1989, 146.

${ }^{101}$ Silbey, A War of Frontier and Empire, 2008, 88.
} 
forgone conclusion, but it was an uphill fight for the anti-imperialist faction that stood against it. The anti-imperialists argued against annexing the Philippines citing more pressing domestic issues, economic problems, and the immorality of forcing American institutions at gunpoint onto another people. Imperialists possessed a majority in the Senate but needed a two-thirds majority to ratify the treaty. Initially, it seemed that they might be short of votes. Their arguments played to patriotism and, rather cynically, to the United States' treatment of Native Americans. A vote against ratification was to say that America was incapable of overseeing the Philippines. To counter those who said that the Filipinos should be granted their self-government imperialists claimed that this same freedom had not been given to the Native American tribes at home, so why should they grant it to Filipinos? In the end, events dictated the outcome of the debate when the fighting started. On February 6, 1899, the Senate voted 57-27 to approve the treaty. ${ }^{102}$

Ratification and the Army's success in the Philippines began to reshape the public's image of the military as well. The Dodge Commission released its report on the Army's shortcomings in Cuba in February of 1899. To the American public, the old Army had been made up of poor enlisted men and stifled officers. To observers, the new Army that fought in the Philippines consisted of energetic volunteers that brought civilization to a new western frontier. Along with the Army's successes, McKinley requested and approved bills from Congress that expanded the size of the regular army and added more volunteer units. ${ }^{103}$

\footnotetext{
102 Ibid., 88-94.

${ }^{103}$ Ibid., 95-96.
} 
The capture of Calumpit represented the end of the Manila campaign. The campaign had been a complete success for the Americans. For the Filipinos, it had been a disaster. The Army of Liberation was unable to stop the Americans or significantly delay their advance. These conditions put its leaders in a difficult position. The summer monsoon season brought a temporary halt to major campaigning. American units, well past their enlistment deadlines, began to go home and be replaced with fresh volunteers from the states.

Aguinaldo faced a supremely difficult task. He recognized the need to reorganize and rebuild his army, but he had limited resources and time. He complicated his difficulties by trying to consolidate his power and had General Luna executed. Aguinaldo's army was fractured, under-equipped, and had poor military leaders. Aguinaldo had two options. He could try and keep the army together and in the field against the Americans, or he could order his troops to break up into smaller commands and wage guerrilla warfare. He chose to keep his army together. The Filipinos had been successful against the Spanish as guerrilla fighters, and committing to that kind of warfare earlier might have yielded better results. By keeping his army together to fight a conventional war, Aguinaldo made both a political and military decision. The Army of Liberation remained as the only real institution of government. Keeping it in the field meant the government still existed. The army gave disparate groups a rallying point and legitimacy as a state, at least in Aguinaldo's eyes. If he broke up the army, then he risked 
further fracturing and losing his claim, both to outsiders and his fellow Filipinos, that the Philippines were a sovereign state. ${ }^{104}$

On the American side, General Otis looked to the fall as his chance to destroy the Army of Liberation and end the war. The Army had no trouble in finding more volunteers after the successes in Cuba and the Philippines and though the Army still faced some logistics issues fresh regiments, including three African American units, replaced those regiments that had gone home. Otis had around 20,000 American troops at his disposal and had begun to recruit Filipino auxiliary units led by American officers to free up more troops for frontline duty. During the spring and summer, the Navy instituted a blockade that greatly hindered communication and support between islands, and Aguinaldo's forces were limited to the resources they had within the islands.

When Otis launched his campaign on October 9, 1899 he split his forces into three columns in the face of the Army of Liberation. The three-pronged attack was designed to pin Aguinaldo's forces in place while columns under Wheaton and Lawton maneuvered behind the Army of Liberation. Once in place, the third column under MacArthur could drive the Filipinos into these blocking forces.

The American plan ran into trouble as heavy rains slowed MacArthur's advance and much of the Army of Liberation escaped. Forces under the command of General Samuel Young captured a proclamation that stated that Aguinaldo intended to move his capital once again, this time into the mountains roughly 75 miles from the American front lines. Young was yet another Civil War veteran. He had enlisted as a private and risen to

\footnotetext{
${ }^{104}$ Ibid., 100-103.
} 
the rank of Brigadier General. Young had fought across the bridge over Antietam Creek at the Battle of Antietam and participated in the Plains Wars. He proposed to pursue and capture Aguinaldo ahead of the main American force while living off the land for his supplies. ${ }^{105}$

On November 7th, General Young took a mixed unit of 1,000 men and pushed ahead in his attempt to capture Aguinaldo. Away from their supplies, Young's small force kept up a close pursuit of Aguinaldo. In the first seven days, they marched 120 miles, but Aguinaldo managed to stay ahead of them. At the village of Pozorrubio on the $15^{\text {th }}$, gunfire warned Aguinaldo that Young's men had almost caught up with him, and he and his bodyguard left town as the American's fought their way into it. By this point, Young needed reinforcements to continue, which met up with his force in the form of a battalion of Texas volunteers. Aguinaldo had fled into the mountains of Central Luzon and left a 60-man rearguard to defend the pass into the mountains behind him. On December 2nd, the Americans reached the chokepoint, and the ensuing day-long Battle of Tirad Pass became christened the Filipino Thermopylae. Sixty Filipinos held the pass dug in behind rocks, and their strong position only broke when a small detachment of Americans scaled a cliff to fire on the Filipinos from above. Only eight of the sixty Filipinos survived, but the delay proved to be enough. Within a week, the Americans ended their pursuit. Many in Young's column had marched on without shoes, on reduced rations, and sick. They had reached their limit. ${ }^{106}$

\footnotetext{
${ }^{105}$ Jones, Honor in the Dust, 2012, 129-30.

${ }^{106}$ Ibid., 133-36.
} 
Aguinaldo managed to escape into relative safety. Although the Americans failed to capture Aguinaldo, they had separated him from his army. During his flight, on December 13th, 1899 Aguinaldo had ordered his army to turn to guerrilla warfare. He had been able to avoid this difficult order since the outbreak of the war. At one point the Army of Liberation stood on the verge of capturing Manilla and possibly completing a campaign to gain independence from Spain. Now a conventional war turned into an irregular one. The Army of Liberation melted into the countryside to wage a different kind of war on the Americans. 


\section{CHAPTER 2: IRREGULAR WAR}

By late December 1899, General Otis' fall offensives had drawn to a close and he turned to occupying the rest of the archipelago. The Army of Liberation seemed thoroughly beaten, and Otis bragged that he could march a 3,000-man column anywhere in the islands and that the insurgents would be powerless to stop him. This sense of impunity, and assurances from Filipino elites in Manila that they wanted annexation, led many Americans to believe the war was over. Even Bell reported that the only remaining resistance was "small bands...largely composed of the flotsam and jetsam of the wreck of the insurrection." ${ }^{107}$

\section{AMERICAN FRUSTRATION}

What remained out of sight for many Americans was the fact that many Filipinos had heeded Aguinaldo's December call to begin a guerrilla war. The remnants of the Army of Liberation used their experience waging war against the Spanish and transformed into an effective guerrilla army. Even as Americans like Bell were assuming that they only needed to mop up isolated armed resistance, the Filipinos were preparing for a different kind of war.

\footnotetext{
${ }^{107}$ James R. Arnold, Jungle of Snakes: A Century of Counterinsurgency Warfare from the Philippines to Iraq, First Edition (New York: Bloomsbury Press, 2009), 19-20.
} 
In early 1900, the U.S. military government began to shift into a new role as administrator over the islands. The Americans began reorganizing the courts, legal codes, and local and regional governments. In the areas that they controlled, Americans also introduced campaigns to improve social conditions. Americans began widespread public health and education campaigns, as they had done when they first occupied Manila. ${ }^{108}$ In all of this, the goal was to show Filipinos the benefits of U.S. rule and convince them of the sovereignty of the United States over the Philippines. Ultimately American officials believed that the war had been won and that they could look to a transition from a military government to a civilian one. ${ }^{109}$

For those Filipinos that remained in the field, the Americans introduced other incentives. One of the key components of continued resistance to the American occupation was weapons. It may seem like an obvious statement, but the Filipinos were short on firearms from the outset. The Americans recognized this weakness and actively tried to exploit it. In late 1899 they had introduced a bounty on any rifle that was handed over. Between November 1899 and April 1900, the bounty netted over 1,000 firearms in Luzon. James Bell during his command of the $36^{\text {th }}$ United States Volunteer Infantry Regiment, one of those units recruited from ex-state volunteers, considered it a success that his unit had captured 775 rifles over the course of seven months. ${ }^{110}$ In just a few months the bounty was more effective than Bell's regiment in the field had been for the better part of a year. The financial incentive was enough to get many Filipinos to

\footnotetext{
${ }^{108}$ Jones, Honor in the Dust, 2012, 98.

${ }^{109}$ Gates, Schoolbooks and Krags, 1973, 129-33.

${ }^{110}$ William R Grove, Record of Operations of Thirty-Sixth Infantry, U.S. Volunteers, from Its Organization in July, 1899 to Date of Muster out in March, 1901 ([Place of publication not identified]: [publisher not identified], 1900), 73.
} 
surrender. One insurgent officer wrote that his whole command would surrender for the bounty if they knew that they would not be imprisoned. ${ }^{111}$

While the Americans busied themselves with occupation and administration, Filipino commanders began to adapt to fighting a guerrilla war. Although the Army of Liberation had been broken up, significant numbers of Filipinos remained ready to continue the war against the Americans. An insurgent commander laid out the plan to fight back against the Americans. He ordered his men to "Annoy the enemy at different points...our aim is not to vanquish them, a difficult matter considering their superiority in numbers and arms, but to inflict on them constant losses, to the end of discouraging them and convincing them of our rights."

Aguinaldo nominally ran the insurgency from his headquarters in Northern Luzon. The islands were divided into districts with a commanding general and subdistricts led by colonels and majors. The fighting men of the insurgency comprised two main groups, former soldiers from the Army of Liberation operating as insurgents fulltime and a part-time militia. This structure depended on the ability of local commanders. Throughout the insurgency, however, Aguinaldo struggled to maintain control from his remote hideout in the mountains of Northern Luzon. Actual responsibility for waging the war fell to subordinates operating almost with near complete independence. Aguinaldo still represented a significant figure, but could do little to influence his commanders. The

${ }^{111}$ Gates, Schoolbooks and Krags, 1973, 147-48.

112 Arnold, Jungle of Snakes, 2009, 21. 
local district commanders often commanded only a few hundred men in a given province that were divided up into smaller bands. ${ }^{113}$

These bands of regulars consisted of the men that had been in the Army of Liberation. They often operated in groups of fewer than 50 and were supposed to be the best equipped. However, the Filipinos were still under-armed for the war. The U.S. blockade of the islands prevented any outside shipments of weapons from reaching the insurgents. They relied on a limited amount of homemade ammunition which prevented adequate practice and frequently misfired. After one engagement, an American officer concluded that 60 percent of the rounds fired at his men had misfired. The rounds that did fire often missed due to the condition of the weapons and a lack of training. The insurgent officer knew their limitations and tried to overcome them by using carefully prepared ambushes to engage the Americans and preserving their strength by quickly withdrawing after a few volleys. These tactics enabled them to maintain their manpower and frustrate the American soldiers. ${ }^{114}$

The part-time militia that made up the rest of the Filipino army maintained the network that kept the regulars in the field. They provided the regulars with supplies, intelligence, and shelter. These bolomen, known for the knives they carried, acted as the local police for the Filipino shadow government. They collected taxes, enforced the rules, gathered intelligence, and protected local officials. To gain civilian support the insurgents appealed to nationalism, ethnic and religious loyalties, and coercion. Civilians

\footnotetext{
${ }^{113}$ Linn, The Philippine War, 1899-1902, 2000, 186-87.

${ }^{114}$ Arnold, Jungle of Snakes, 2009, 21-22.
} 
that aided the Americans or did not support the insurgency were subject to fines, beating, property destruction, or even death. ${ }^{115}$

As the Filipinos laid the groundwork for their guerrilla strategy, the Americans began to implement their policy of attraction. During the first half of 1900 , the Americans assumed that the Filipinos had peacefully accepted their defeat and were at least tolerant of American rule. This assumption was out of touch and hampered by poor intelligence. Regardless, the Americans began a campaign to provide vaccinations, jobs, and schools. The program relied on low-level officers in charge of individual garrisons to administer local government and aid to Filipino citizens. It was the fulfillment of America's plan for benevolent assimilation. Americans saw that it was their duty to aid a society that was incapable of self-rule. In many regions, American efforts at this kind of governance succeeded. A local garrison, stability, and improvements to the local society garnered loyalty from civilian populations that had already suffered enough fighting, or that had not been particularly loyal to the revolution in the first place. Success in these more peaceful areas even contributed to hiding the growth of the insurgency in others, as both Otis and his replacement, MacArthur, thought the insurgents to be on their last legs during the winter of 1899-1900. MacArthur considered his offer of amnesty in June of 1900 to be a gesture to end the war and attract the final holdouts of the insurgency to surrender. ${ }^{116}$

Even as these programs began, the fighting continued. Insurgents raided communication lines, supply columns, and even led one American General to write that

\footnotetext{
${ }^{115}$ Ibid., 22-23.

${ }^{116}$ Gates, Schoolbooks and Krags, 1973, 148-49.
} 
defeat might be at hand. In addition, the insurgents continued to intimidate civilians and in just 1900 alone the Americans recorded over 300 assassinations and over 400 assaults. By April 1900, Bell had changed his tone from comparing the insurgency to flotsam. He reported that his command in Southern Luzon was unable to control more than a few towns, and could not control the surrounding territory. ${ }^{117}$ Even with an apparent defeat of Aguinaldo's standing army and the bulk of the U.S. Army garrisoning the Philippines, the Americans could not provide enough security to end the war that they had assumed to be won. $^{118}$

Initially, during the rush to enlist at the outbreak of the Spanish-American War, the U.S. Army struggled to cope with the rapid expansion. The army struggled to equip, train and move, both its regular and volunteer units during initial war with Spain. By the time that Aguinaldo disbanded the Filipino Revolutionary Army in December of 1899 , the U.S. Army had largely overcome these problems. New regulars and volunteers alike received better training. Many of the units now had combat experience from the previous year's fighting. When state volunteer regiments returned home, many men signed on with new United States Volunteer regiments. Many of the initial volunteers that fought in the Philippines had been from Western states. ${ }^{119}$ They had performed well and frequently re-enlisted with new units. The volunteer regiments that formed had large numbers of experienced soldiers in addition to new recruits. ${ }^{120}$

\footnotetext{
117 Jones, Honor in the Dust, 2012, 143.

118 Arnold, Jungle of Snakes, 2009, 23-25.

${ }^{119}$ Silbey, A War of Frontier and Empire, 2008, 95,105.

${ }^{120}$ Arnold, Jungle of Snakes, 2009, 26.
} 
The senior officers of the army possessed experience that dated back to the Civil War. While their combat experience may have seemed dated, they had firsthand knowledge of the March to the Sea or Sheridan's Valley Campaign, along with campaigns to pacify the Native American tribes living in the American West. Out of thirty American Generals that served in the Philippines, twenty-six participated in the Indian Wars. Among the four that had not, Frederick Funston had volunteered with the Cuban revolutionaries fighting against Spain. ${ }^{121}$ The lower ranking officers that had spent years with little to no prospects for advancement had learned to be comfortable commanding small unit actions and remote garrisons in the American West. This experience from the Civil War to the Western Frontier had helped to develop a method of waging counter-insurgency warfare within the army. Commanders used tactics that would later see widespread use in the Philippines, including population control, destruction of property and resources, and retaliation for continued resistance. While the Army struggled to respond to the initial declaration of war, it was well equipped for the coming guerrilla war. ${ }^{122}$

Although violence increased in the islands in the spring and summer of 1900, it is important to remember that during this period the war remained highly localized. While the Filipino Army was still together American efforts centered on its destruction, but even as Aguinaldo spread his men through the provinces to fight back, many areas remained peaceful. In thirty-four of the seventy-seven provinces in the Philippines no

\footnotetext{
${ }^{121}$ Max Boot, The Savage Wars of Peace: Small Wars and the Rise of American Power, Revised Edition (New York: Basic Books, 2014), 127-28.

${ }^{122}$ Linn, The Philippine War, 1899-1902, 2000, 9.
} 
fighting took place. Despite almost half of the islands seeing no fighting, the upcoming pacification campaign required a commitment of most of the army's resources. ${ }^{123}$

By October of 1900, there were 70,000 U.S. soldiers stationed in the Philippines. This was at a time when the authorized strength of the regular army was still under 100,000 men. To combat the insurgency and establish a civil government they were stationed in over 400 different garrisons. Even if they could concentrate in each one, there would be fewer than 200 men per garrison to fight the insurgency and carry out civil rule. The numbers were often much smaller than that. The garrisons required constant resupply that relied on poor or no infrastructure and the re-supply columns made ideal targets for insurgent ambushes. ${ }^{124}$

The troops not engaged in supply and civil administration tried to combat the insurgency by launching patrols into the countryside. They made use of mounted infantry and cavalry when they could, or carried a light load when they could not. Bell's command marched with just 150 rounds of ammunition, rifle, canteen, cup, half a mess kit, utensils, first aid kit, towel, and a poncho or shelter half. His infantry regiment, which he claimed was never up to its authorized 1,000-man strength, made use of up to 150 horses for communication and chasing down insurgents, in addition to its pack train for supply and any horses privately owned by officers and men. ${ }^{125}$

\footnotetext{
${ }^{123}$ Ibid., 185.

${ }^{124}$ Arnold, Jungle of Snakes, 2009, 27-28.

${ }^{125}$ Grove, Record of Operations of Thirty-Sixth Infantry, U.S. Volunteers, from Its Organization in July, 1899 to Date of Muster out in March, 1901, 83-84.
} 
These patrols often faced difficult terrain, but their greatest obstacle was poor intelligence. During the initial year of the guerrilla war, the insurgent intelligence network was still strong, and the U.S. often did not have the trust or control of the civilian population to prevent them from warning insurgents. American officers aggressively pressed any engagement because opportunities to fight the insurgents were limited and they did not have a high regard for the insurgent's skill in a prolonged firefight. ${ }^{126}$

Aggressive American tactics did not always win the day. A company of the 15 th Infantry Regiment under the command of Captain David Mitchell launched an assault on the town of Matibac in Southern Luzon in order to eliminate an insurgent stronghold there, and capture insurgent General Juan Cailles. As many as 800 insurgents outnumbered Mitchell's 130-man company, but he continued with the attack regardless. American soldiers had to approach the town over a long causeway flanked by flooded ground on either side. While Mitchell led part of his company up the causeway, another part of the company moved into a flanking position and attacked from a second direction. Flooded terrain delayed the flanking party, and the insurgents concentrated their fire on Mitchell and the men he led down the causeway. Despite their poor equipment, the insurgents found the Americans to be easy targets, and Mitchell's men found themselves caught in a crossfire and retreated.

Mitchell's headlong attack led to 23 Americans killed and 19 more wounded. Mitchell was among the dead, and while MacArthur praised the soldier's courage publicly, he confided that if Mitchell had survived, he would have ordered him court-

${ }^{126}$ Arnold, Jungle of Snakes, 2009, 28-29. 
martialed. To deepen the injury, the American forces that returned the following day found no Filipino fighters. The insurgents had melted into surrounding towns and villages as civilians. Mitchell's attack was foolish, but it came from a widespread desire to simply engage the enemy. The opportunity to bring insurgents to battle at Matibac outweighed the tactical disadvantage that the Americans faced there. This style of combat which frustrated the Americans earned the name "Amigo Warfare" among officers and soldiers. Insurgents could be beaten or driven off, and then later blend in with the civilian population, their arms hidden until the next opportunity to fight. Many American soldiers failed to distinguish the civilian population from the insurgents, and the insurgents used this advantage as much as they could. ${ }^{127}$

American troops in the Philippines often exacerbated their tense relationship with the civilian population. They commonly drank which often led to fights. Soldiers would take food or other supplies from villagers, and at the end of the spectrum, they would retaliate violently against nearby civilian populations when a comrade was killed. Many Filipino civilians were simply caught between the two sides. The people that lived life between the soldiers and insurgents had to cope as best as they could. In most towns, it led to the population supporting the Americans by day and the insurgents by night, they had to try and appease both sides while risking the wrath of each. ${ }^{128}$

Drinking and fighting were not the only clashes between the two cultures. From the beginning of the war, reports alleged American atrocities against Filipinos. Describing the Battle of Manila, a soldier had written home that his Washington regiment

\footnotetext{
${ }^{127}$ Silbey, A War of Frontier and Empire, 2008, 153-55.

${ }^{128}$ Arnold, Jungle of Snakes, 2009, 31-32.
} 
had killed more than 1,000 Filipinos, including women and children, and that they had burned down all their houses. He went on to allege that the Tennessee regiment nearby refused to take any prisoners. Another sergeant wrote that whenever they found a wounded insurgent that he and his men resorted to bayonets to kill them. Allegations quickly arose from a private in Frederick Funston's Kansas regiment that officers had ordered to kill prisoners and that the man had been ordered by his colonel to shoot four prisoners. Later the allegations grew that Funston used his rank and position to prevent a fair investigation. ${ }^{129}$

It is difficult to corroborate the soldier's claim of 1,000 killed, especially considering that total number of Filipino dead for the entire Battle of Manila was likely less than 1,000. How often American soldiers killed prisoners or noncombatants is unclear. The allegations kept appearing, often in American newspapers as letters from soldiers, but official charges or trials rarely followed. A later study claimed that there were 57 incidents during the Philippine-American War which met a legal definition of atrocity. ${ }^{130}$ In addition to defined atrocities, casualty reports often returned high numbers of Filipino dead, often several times greater than the number of wounded, unusual for any

\footnotetext{
${ }^{129}$ Moorfield Storey, Julian Codman, and YA Pamphlet Collection (Library of Congress) DLC, Secretary Root's record. "Marked Severities" in Philippine Warfare. An Analysis of the Law and Facts Bearing on the Action and Utterances of President Roosevelt and Secretary Root (Boston, G.H. Ellis co., printers, 1902), 10-20.

${ }^{130}$ David R. Hogg, "The Legal Use of Terror as a Weapon” (DTIC Document, 1992), 5-16, http://oai.dtic.mil/oai/oai?verb=getRecord\&metadataPrefix=html\&identifier=ADA255168.
} 
conflict. The statistic suggests a willingness on soldiers' part to carry out "no prisoners" orders. ${ }^{131}$

The problem may have been more extensive, as Bell and other officers claimed that although they issued orders against these acts, they had little ability to stop them outside of their immediate presence. An officer named Henry Allen wrote,

"You, as well as I, know that in bringing to a successful issue war measures out here certain things will take place not intended by the higher authorities; that the 'water cure' and other unauthorized methods will be resorted to in spite of the strictest instructions. I have heard that under me, although against my orders, the 'water cure' and other measures just as bad, or worse, were adopted, and probably under you the same; moreover, it can be said that such things have taken place under all commanders out here." ${ }^{132}$

The torture method known as the "water cure" that Allen wrote about was widely used by the Americans to interrogate prisoners. The actual method was described by an American soldier as follows.

"A man is thrown down on his back and three or four men sit or stand on his arms and legs and hold him down;... a carbine barrel or a stick as big as a belaying pin, and, if possible, a wooden log or stone is put under his head or neck, so he can be held more firmly. In the case of very old men I have seen their teeth fall out, -- and I mean when it was done a little roughly. He is simply held down and then water is poured onto his face down his throat and nose from a jar, and that is kept up until the man gives some sign or becomes unconscious. And then...he is simply...rolled aside rudely, so that water is expelled. A man suffers tremendously, there is no doubt about it."133

\footnotetext{
${ }^{131}$ Storey, Codman, and YA Pamphlet Collection (Library of Congress) DLC, Secretary Root's Record. "Marked Severities" in Philippine Warfare. An Analysis of the Law and Facts Bearing on the Action and Utterances of President Roosevelt and Secretary Root, 22-23.

${ }^{132}$ Linn, The Philippine War, 1899-1902, 2000, 223.

${ }^{133}$ Hogg, "The Legal Use of Terror as a Weapon," 5-17.
} 
Allegations of torture and atrocities stirred anti-imperialist voices in the United States. 1900 was a U.S. presidential election year, and the Democrat candidate William Jennings Bryan campaigned on anti-imperialism. Aguinaldo, keenly aware of this, knew that it was his best time to impact American policy. He ordered his forces to increase their attacks on American outposts to try and inflict losses that would hurt McKinley's chance of re-election. Aguinaldo's plan was likely his best opportunity to impact the U.S. occupation significantly, but it also meant that McKinley's re-election became a severe blow to the Filipino cause. ${ }^{134}$

While Aguinaldo was aware of the election season, he overestimated the chance of McKinley losing the election. Aguinaldo also underestimated the American response to increased insurgent activity. McKinley's opponent William Jennings Bryan had lost an election bid four years before, and his main platform had been about economics centered on his "Free Silver" policy. His campaign now faced an incumbent president who had overseen a successful war against Spain and a better economy than during the last election. Bryan faced an uphill battle to win the election, and his main chance to stand out from McKinley was his opposition to annexing the Philippines.

Unfortunately for Bryan, this position failed to resonate with many Americans. Anti-imperialists in the U.S. protested the war, but they never held a majority position. Aguinaldo had little opportunity to gain an accurate appraisal of the U.S. political climate. His campaign to increase publicized attacks failed to achieve a meaningful impact. Reporters tried to write on the increased attacks but the American military began

${ }^{134}$ Silbey, A War of Frontier and Empire, 2008, 149-50. 
strict censorship policies to ensure that word of any American losses stayed in the Philippines. Army censors delayed reports, prohibited the use of the word "ambush," and inflated their successes. One report cited that the army had captured 800 insurgents and their firearms. When a reporter investigated further, he found that only 40 rifles had been captured, and the Army added in any other weapons they found to the count. ${ }^{135}$

As 1900 wore on the insurgents saw some hope for their campaign, but with McKinley's victory, a positive outcome became impossible. The Americans had been able to defeat the revolutionary army in battle, but not end the insurgency. Despite an ongoing adherence to "benevolent assimilation" and its building programs, new roads, schools, public health campaign, and civil administration, the American campaign was far from over. It still could not prevent widespread insurgent support or attacks. Even if these attacks could not end the American occupation, they prevented full American rule.

To implement American governance of the islands, McKinley dispatched the Philippine Commission under future President William Taft. When Taft arrived in June at the head of the commission, his purpose was to provide the Filipinos with an effective civilian government. Initially, the commission assumed legislative power in the islands. As the military declared provinces to be "pacified" they would be handed over to the authority of the commission until the entirety of the Philippines was under civilian governance and Taft would become governor of the territory. ${ }^{136}$

\footnotetext{
${ }^{135}$ Arnold, Jungle of Snakes, 2009, 33.

${ }^{136}$ Linn, The Philippine War, 1899-1902, 2000, 216.
} 
In the meantime, Taft repeatedly clashed with the military and General Arthur MacArthur, now head of the army in the Philippines. Each side resented sharing authority with the other and had different views on how to end the war. Taft's optimistic outlook on the conflict and paternal view of the Philippines also stood against the way that many American soldiers viewed Filipinos. After Taft had referred to Filipinos as "Our little brown brother" soldiers created new lyrics for a then popular tune to explain their feelings.

"I'm only a common soldier man in the blasted Philippines, They say I got Brown Brothers here, but I dunno what it means. I like the word Fraternity, but I still draw the line; He may be a brother of William $\mathrm{H}$.

Taft, but he ain't no friend of mine."137

This soldierly view of the Filipinos echoed sentiments of American officers as well. From top to bottom, the American military in the Philippines did not trust the new civilian administration to get the job done and viewed most of the population with mistrust or as outright collaborators with the insurgency.

\section{INSURGENCY REVEALED}

As the insurgents carried out more direct attacks on American troops and outposts during their election season offensive, Americans began to realize that they needed to change their approach. MacArthur himself suspected that the majority of Filipinos were loyal to the insurgency. Much of the insurgent support relied on intimidation or force. Filipinos who were willing to stop supporting the insurgency and provide their loyalty to the Americans needed protection. If Americans could not provide some measure of

${ }^{137}$ Arnold, Jungle of Snakes, 2009, 35. 
security and support to those loyal to their cause, they would never be able to end the war. Taft concluded after his initial tour of the islands that most civilians wanted peace but feared reprisals.

Taft's view differed from MacArthur, who still assumed that civilians would provide spoken loyalty to the Americans and get the benefits that their loyalty entailed, while still maintaining active support for the insurgency. The reasons that American officials and officers could look at the Philippines and come away with such different conclusions was due in part to the regional differences in the provinces, but much more important, until the summer of 1900 , few on the American side had a clear understanding of how the insurgency operated.

That changed in June 1900 when Lieutenant William Johnston sent a report to MacArthur titled "Methods Adopted by Insurgents for Organizing and Maintaining a Guerrilla Force." This report contained the information from several months of investigation and work by Johnston in the province of La Union. La Union was located in Northwestern Luzon 170 miles from Manila. Johnston suspected more to the insurgency than a few local bands and that they needed support to stay in the field. He began a thorough investigation and soon started to learn about the shadow government operating in areas previously thought pacified. Johnston used a local cult leader that had strained ties to the insurgency to begin naming figures in the resistance. Johnston first used his informant to uncover insurgent officers and stockpiles in the town of Bauang. The 
network he had started to uncover showed Johnston that the insurgent government had been operating within American controlled areas with relative impunity. ${ }^{138}$

Johnston learned that insurgents had infiltrated many levels of civil government even in those towns that had significant numbers of American troops. He also found out that they gained supplies and taxes from the local population and by skimming from American aid. His intelligence showed that insurgent bands often camped by local towns, even those with American garrisons to enforce the authority of this shadow government and that even high-ranking insurgent leaders could move in and out of American-controlled areas. In La Union, this information was both a shock and finally a means to combat the insurgency effectively. Johnston used the original cult-leaderturned-counterinsurgent to recruit a Filipino volunteer force, which consisted initially of mostly his cult followers, to begin naming and arresting suspected insurgents. ${ }^{139}$

Those arrested could prove their loyalty to the Americans by turning over more information or former comrades, which provided more intelligence to the Americans and guaranteed that the prisoner could not rejoin the insurgency. The Americans appointed loyal Filipinos to the important civil positions and regained control in towns that had previously served as safe havens for the shadow government. In the course of a few months, the province had been declared pacified. MacArthur received the report in June and made the decision that American strategy needed to change. He also recognized that a public acknowledgment of the American failure to finish a war that had seemed to be won a few months before would give fodder to rising anti-imperial sentiment back home.

\footnotetext{
${ }^{138}$ Ibid., 38.

${ }^{139}$ Ibid., 39.
} 
MacArthur knew that he needed to wait until after the election to enact the harsh measure he now thought necessary to end the war. Anti-imperialist voices back home faced strong opposition from those that supported the war, annexation, and McKinley. They were labeled unpatriotic and accused of aiding the insurgency. The New York Tribune even attacked William Jennings Bryan by saying that "Every American soldier killed during these months can be laid directly at his door."

Following McKinley's victory in the 1900 election, MacArthur began to implement a new strategy in the Philippines. This new effort, based on Lt. Johnston's work, represented a major shift from a "policy of attraction"141 that had been the overall American strategy until this point. MacArthur's strategy took a hard turn. He outlined that static garrisons would continue to protect important towns, but additional more mobile forces were to be assigned to conduct sweeps of insurgent territory to root out the bands still fighting the Americans. Also, the Americans began to recruit more native auxiliaries to supplement their manpower. This new push began in December, after the election, but this reorganization of American efforts represented only part of the change that MacArthur implemented in the fall of $1900 .^{142}$

\footnotetext{
${ }^{140}$ Ibid., 38-40.

${ }^{141}$ The terms "Policy of Attraction" and "Benevolent Assimilation" generally refer to the same concept. The idea that Americans were there to help the Filipinos and if they could show the benefits of American rule then Filipinos would accept American authority. "Policy of Attraction" was more commonly used as a phrase that we might replace today with "winning hearts and minds." It was a more direct interaction as part of the counter-insurgency campaign, comparable to the modern Provincial Reconstruction Teams used in Afghanistan. "Benevolent Assimilation" was more broadly used when describing the high-level policy or overall American intentions.

${ }^{142}$ Silbey, A War of Frontier and Empire, 2008, 165-66.
} 
The legal basis for MacArthur's shift was the Lieber Code, also known as General Orders 100. ${ }^{143}$ Since the beginning of the war American forces had been operating under this standing order which dated to U.S. Civil War. While official American policy during the Philippine-American War had been "Benevolent Assimilation", the Army had been operating under G.O. 100. The dichotomy between official policy and local enforcement created a situation where commanders operated under their interpretation of the order, and how to make it fit with the broader policy of attraction. In practice, many commanders resorted to the punitive sections of G.O. 100 to combat the insurgents, while the American command in Manila officially practiced attraction. In late December, MacArthur issued a proclamation to the Philippine people and his men that the Americans were now using the full measure of the G.O. 100. This shift bridged the gap between official and de facto policy and made it clear that anyone who still opposed the Americans faced intense repercussions. ${ }^{144}$

A lawyer named Frances Lieber wrote General Orders 100 during the Civil War in 1863. Lieber's code became the first documented "laws of war." The document was meant to be a standing order that governed the Union Army and laid out standards of conduct for both combatants and noncombatants. When Lieber wrote G.O.100 the hostile territory and enemy combatants were the Confederates in the American South, now the hostile forces were the Filipino insurgents. G.O. 100 especially focused on the treatment of anyone operating as a guerrilla and their supporters. The punishment for this kind of warfare could be stringent, including summary executions, and Lieber made clear

\footnotetext{
${ }^{143}$ The Lieber Code Of 1863, accessed at http://archive.org/details/pdfy-NG4E2nsEimXkB5mU.

${ }^{144}$ Linn, The Philippine War, 1899-1902, 2000, 215-16.
} 
that guerrillas were not to be treated as enemy soldiers. Anyone that aided guerrillas could have their property destroyed. MacArthur released the proclamation to give notice that remaining insurgents were in violation of the laws of war as written in General Order 100. He had offered an amnesty during the summer that had failed to net any major leaders of the insurgency, and he sought to use G.O. 100 as the harsh alternative. ${ }^{145}$

Some American officers had already used General Order 100 as justification for harsh policies. American forces resorted to burning crops and homes, arresting suspected insurgents, or even shooting suspected saboteurs on sight. For those officers that had been employing these tactics, the announcement came as a tacit acceptance that they had been right. For others, it came as the signal to begin waging a hard war on the insurgents, some of whom had believed that once the war was over their lives could return to normal with their status or property unharmed. Ultimately the goal of the new policy was not just to bring destruction to the Philippines for resisting the Americans, but to separate the active insurgents from any base of support, and to force those Filipinos in the middle to actively pledge their loyalty to the Americans. By implementing stern measures, MacArthur hoped to make the consequences of continued resistance too great. Lieber's stated goal of General Orders 100 was to achieve peace. To bring peace MacArthur decided to destroy the insurgent's support network, not just to convince the population of America's ability to govern the Philippines, as had been the main object of the policy of attraction. ${ }^{146}$

\footnotetext{
${ }^{145}$ Silbey, A War of Frontier and Empire, 2008, 156-58.

${ }^{146}$ Arnold, Jungle of Snakes, 2009, 42-43.
} 
The beginning of 1901 saw the full force of this new strategy begin to have an impact on the islands. MacArthur centered his efforts and his 70,000 troops on the main island of Luzon. He assumed that bringing an end to the insurgency on the largest island would have a domino effect on the rest. Along with more aggressive soldiering, the new year saw the rise of the Filipino Federalist Party. The Federalist Party formed from Filipino elites that had decided that the way forward was to recognize American sovereignty in the Philippines. They began a campaign to persuade fellow Filipinos to their cause and offered an alternative means of political representation for those outside of the Aguinaldo's government. Their belief that the U.S. had won was both pragmatic, as they recognized the fact that anyone who continued to resist would be kept out of the postwar government, and patriotic as they still believed in a potential political independence for the Philippines. ${ }^{147}$

Throughout the beginning of the new year of 1901 support for the insurgents began to erode. MacArthur's efforts, American reinforcements, and Mckinley's election combined to wear down the insurgents. Between December 1900 and July 1901, resistance ended in twenty-one of the thirty-eight provinces that still held out against the Americans. Where efforts before had failed to bring in insurgent leaders, they too began to capitulate. To drive home the point and to signal the end of the war was close at hand the Army launched a raid to capture Aguinaldo. ${ }^{148}$

Aguinaldo had been in hiding since the defeat of the Revolutionary Army and his decision to transition to guerrilla warfare. He tried to manage the insurgency from a

\footnotetext{
${ }^{147}$ Ibid., 44-45.

${ }^{148}$ Linn, The Philippine War, 1899-1902, 2000, 214-15.
} 
hidden headquarters in the mountains of northern Luzon. However, he could only manage to exercise limited command and control of his forces through written communications to subordinates and proclamation to the Filipino people. With communications already difficult for insurgents, Aguinaldo's influence over his commanders waned. The conflict became much more regionally focused once the Filipinos began their guerrilla campaign, yet Aguinaldo was still an important symbol for Filipinos who still believed they could win independence.

His capture began with a courier. In January of 1901, an insurgent messenger asked a mayor that had been part of the shadow government for safe passage past the Americans. Unfortunately for the messenger and the insurgency, the mayor was now loyal to the Americans. With the mayor's help, American forces captured the messenger who was carrying about twenty letters. Among the letters was a request from Aguinaldo to his cousin that asked for reinforcements to bolster his headquarters in Palanan. The location was the final piece the Americans needed to strike, and Aguinaldo's need for reinforcements provided the means. With this information, American Brigadier General Fred Funston formulated a plan to capture the insurgent leader. ${ }^{149}$

Funston had won the Medal of Honor two years before, when, during the Battle of Calumpit he led twenty-two volunteers from his Kansas regiment to take an enemy position by crossing a river under fire. ${ }^{150}$ His plan to capture Aguinaldo needed all of his bravery. Funston, along with four other American officers, were to be led as "prisoners" by 80 Macabebe Scouts dressed and armed as insurgents. A gunboat deposited them

\footnotetext{
${ }^{149}$ Silbey, A War of Frontier and Empire, 2008, 173-75.

${ }^{150}$ Linn, The Philippine War, 1899-1902, 2000, 97.
} 
within insurgent territory and they proceeded to march 100 miles to Aguinaldo's headquarters. To aid in their raid, Funston forged two letters on captured insurgent paper that appeared to have been written by a Filipino commander that Aguinaldo trusted. During the march, Funston relied on several ex-insurgents to lead the way and help fool any actual insurgents they came across. When Funston's force arrived, the ruse worked. Aguinaldo turned out his honor guard to greet them. The Macabebes formed up opposite the honor guard and instead of firing a salute opened fire on the guards. As the volley erupted, one of the ex-insurgent officers ran to capture Aguinaldo, shooting two more of his guards in the process. Among MacArthur's staff some officers thought the raid would end in disaster, but instead, it was a complete success. Funston had captured Aguinaldo and made the rendezvous with the gunboat to return to MacArthur's headquarters. ${ }^{151}$

Aguinaldo's capture did not end the war, but it did cause some important guerrilla leaders to surrender along with some of their men. Aguinaldo's capture represented a definite success for the Americans in an often-frustrating war without tangible victories. For many insurgents though, Aguinaldo was too remote of a symbol for them to give up the fight. They had been loyal to their local commanders before his capture and continued to be. If the local commanders fought on then so did their men. The conclusion of the war fell to MacArthur's successor, Adna Chaffee. ${ }^{152}$

\footnotetext{
${ }^{151}$ Silbey, A War of Frontier and Empire, 2008, 175-77.

${ }^{152}$ Arnold, Jungle of Snakes, 2009, 47-49.
} 


\section{CHAPTER THREE: HARD WAR}

When Chaffee assumed command in July of 1901, he wanted to begin a more thorough transfer of power to the Philippine Commission. Initially, he maintained the policies that had been successful under MacArthur. However, Chaffee felt that the Army still occupied too many areas and that his troops needed to be released from pacification to be better used in fighting the remaining hotspots of the insurgency. Two insurgent strongholds remained, in the province of Batangas and on the island of Samar. Although the change in tactics brought about by MacArthur had been withering for the Filipinos, several strong groups of insurgents, including those on Samar and in Batangas, still held out against American rule. ${ }^{153}$

Chaffee had joined the Army at the outbreak of the Civil War as a private. By 1864 he was a Second Lieutenant as part of General Sheridan's command. Sheridan's campaign through the Shenandoah Valley that year targeted both the Confederate Army and the supplies that they used. Union forces undertook a campaign to destroy anything that could be of use to their enemies to try and speed up the end of the war. Chaffee was familiar with hard war and his mandate to defeat the insurgency had a similar basis. He allowed his commanders to use the harshest measures mandated under G.O. 100 to end

${ }^{153}$ Linn, The Philippine War, 1899-1902, 2000, 215-19. 
the war as soon as possible and James Franklin Bell would be one of the top picks to implement Chaffee's strategy. ${ }^{154}$

As Chaffee took over in the late summer of 1901, the Philippine-American War looked to be finally nearing an end. MacArthur's tenure in the islands saw a major intelligence breakthrough and widespread dismantling of the insurgency. The years of war had shaped the American Army into an effective counter-insurgency force. Although at times thrust into roles and missions that it had not anticipated, the Army had adapted well to this method of war. For James Franklin Bell this war had been a chance to finally advance in rank, and he had proven to be an excellent officer. His tenure in the Philippines had led to a rise to the rank of Brigadier General. He had fought the insurgency all over the islands and at nearly every level of command. His knowledge of counter-insurgency warfare, built on U.S. Army history, doctrine, and his experience in the Philippines would be vital to the success of his coming campaign in Batangas province.

The event that precipitated Bell's assignment occurred on September 27th, 1901. Filipino insurgents infiltrated the town of Balangiga on the Island of Samar and surprised the American garrison in an early morning attack. The residents of the town aided the insurgents who were only armed with knives that they had smuggled into Balangiga leading up to the assault. Tensions in Balangiga had been high recently between the soldiers and Filipinos. The new garrison commander, Captain Thomas Connell, had received several allegations of rape against his soldiers and had been forcing the Filipinos

${ }^{154}$ Ibid., 219. 
to clear underbrush and debris from the town. In addition to these tensions, the island was in the middle of the Cholera outbreak. This outbreak provided cover for the insurgents to smuggle knives into the town.

The night before the attack American sentries noticed residents carrying an unusual number of caskets into the church. When they checked, the Filipinos told the Americans that the caskets contained recent Cholera victims. The excuse, combined with Connell's recent warnings against aggravating the already high tensions was enough for the American sentries to allow the "funeral" to continue. ${ }^{155}$

The unit assigned to garrison Balangiga was Company $\mathrm{C}$ of the 9th U.S. Infantry Regiment. Company $\mathrm{C}$ had previously fought in the Philippines and then in the Boxer Rebellion in China before its assignment to garrison Balangiga. On the morning of September 27, 1901, most men of this veteran unit were eating breakfast when the town's police chief shot the armed sentry with his own rifle; the remaining soldiers were unarmed. After killing the sentry, insurgents rang the church bell to signal the all out attack on the American garrison. ${ }^{156}$

Although the Filipinos attacked only with knives and bolos, they had the element of surprise. Since many of the American soldiers were away from their rifles, the fighting was hand to hand combat, with the Americans at a decided disadvantage. American soldiers fought back with whatever they had available, including rocks and reportedly even a baseball bat, but they had to fight their way to their rifles. The Filipinos knew that to capitalize on the surprise, they needed to prevent the Americans

${ }^{155}$ Miller, Benevolent Assimilation, 200-202.

${ }^{156}$ Ibid., 202-3. 
from getting to their guns and detailed part of their attacking force to make sure of that. Despite this, some soldiers did manage to make it to their guns and organize a fighting retreat down to the shoreline. From there the survivors kept the Filipinos at bay while they managed to get onto boats and make an escape. ${ }^{157}$

The Filipinos inflicted forty-eight deaths on the American garrison and probably lost between twenty-five and thirty of their men. To the American Army in the Philippines, the attack was a complete shock. For many Americans, in the summer of 1901, the war seemed nearly won. Efforts under MacArthur and Chaffee appeared to have broken up the insurgent shadow government and forced the bands of insurgents that were left to be always on the run, barely able to feed themselves, much less organize a major attack against an American outpost.

Officials and soldiers quickly dubbed the attack the Balangiga Massacre. Although the battle had been one-sided and had the galvanizing impact of a massacre to the Americans, in reality, it was a well-organized insurgent assault planned to overcome the American advantage in firepower. Unfortunately for the residents of Samar, the distinction between battle and massacre was lost on the U.S. Army and the American public. In newspapers back in America the attack was compared with Custer's Last Stand and labeled as treachery on the part of the Filipinos. Specific reprisal for the assault at Balingiga was swift and decisive. An infantry company that included six of the survivors returned to the town aboard a navy gunboat. When they arrived, they razed

${ }^{157}$ Silbey, A War of Frontier and Empire, 2008, 191-93. 
Balingiga. Their commander sent a matter of fact message back to Chaffee, "Buried dead, burned town, returned Basey." 158

The shock of Balangiga caused a panic at the American headquarters in Manila. American intelligence began reporting that the insurgents were preparing a new round of uprisings for the beginning of 1902 just as they had during the American election season of 1900. These Army intelligence reports and the attack at Balangiga stood in stark contrast with the reports from Taft and the Philippine Commission that the insurgents were nearly beaten. Chaffee sided with his intelligence service. To him, the war should have been over by now, and the attack was a reminder that American policies had failed so far to end the war. Chaffee reorganized the existing districts into brigade commands and looked for officers to bring the war to a close. ${ }^{159}$

In reality, Taft's assessment was correct, and the insurgency was close to being defeated. While some insurgent bands remained in the field and tried to continue the war, they had been doing so on ever shrinking resources. The attack at Balangiga did not signal a revival of the insurgency. Unlike the increased attacks during the summer of 1900, this well-planned and executed attack marked the maximum effort that the Filipinos could muster at this late stage of the war. The Balangiga Massacre was a last gasp for the Filipinos, and it happened on Samar which was home to some of the last holdouts of the insurgency. The shock of the attack resonated because Samar had earned a reputation as a particularly challenging area for the Americans to subdue, and because

\footnotetext{
${ }^{158}$ Miller, Benevolent Assimilation, 204. The message was just one short sentence. Basey was the name of town that they returned to which was another nearby American garrison.

${ }^{159}$ Arnold, Jungle of Snakes, 2009, 52-53.
} 
the assault was the worst loss in a single engagement for the Americans in the entire war. $^{160}$

Chaffee had been in command since July and was familiar with hard war campaigns. He was a Civil War veteran that had fought in General Sheridan's Shenandoah Valley Campaign, and the Plains Wars. The attack on Balangiga led him to authorize extreme measures to bring the war to an end. He had already recognized that Batangas province, which Bell would command, was still hostile to American rule. To defeat the insurgency on Samar, Chaffee picked General Jacob Smith. The campaigns that Smith and Bell would wage had a new urgency following Balangiga. The extreme measures that Chaffee authorized later led to a Senate inquiry that would bring widespread negative publicity to the two campaigns and damaged the army's reputation. $^{161}$

Jacob Smith was another Civil War veteran. He had been wounded at the Battle of Shiloh, and the bullet remained in his hip for the rest of his life. He had damaged his career through misconduct. Smith had improperly used recruiting bounties during the Civil War and in the post-war Army, he had been subject to a court-martial which eventually led to his conviction and sacking. Grover Cleveland saved his career, and when war broke out with Spain, Smith received orders to Cuba. He suffered a bullet wound at the Battle of El Caney and following his recovery he transferred to the Philippines.

\footnotetext{
${ }^{160}$ Silbey, A War of Frontier and Empire, 2008, 189.

${ }^{161}$ Linn, The Philippine War, 1899-1902, 2000, 219-20.
} 
It was in the Philippines that he earned his promotion to a Brigadier General as the Philippines proved to be an opportunity for long withheld advancement. In light of the Balangiga attack, Chaffee encouraged a harsh prosecution of the war in the hope that it would bring about a quicker end. Whatever degree of harshness Chaffee authorized, Smith implemented it even further. He ordered a complete blockade of the island and forced inhabitants into reconcentration zones with anything outside these zones considered a target. Smith became notorious for his quoted intent to turn Samar into a "howling wilderness" and eventually, his actions on Samar required Chaffee's personal intervention to scale back the violence. One officer later wrote "We did not take any prisoners. We shot everybody on sight."162

Aside from Samar, the other area of the Philippines which still had an active insurgency was the Second District, Department of the Southern Luzon. This region, not far south of Manila, incorporated the provinces of Bataganas, Laguna, and Tayabas. As a whole, the U.S. Army often referred to it as just the Batangas region or province, or more widely, as Southern Luzon. These three provinces encompassed 4,200 square miles and 560,000 residents. Although the impact of the war damaged the area, the region was still one of the wealthiest and most densely populated in the Philippines. The district had been a hotbed of resistance to outside rule since the initial revolt against Spanish rule in the 1890 s. Many of the region's wealthy citizens had pushed for reforms in Spanish rule and began organizing a rebellion when these reforms failed to appear. For American soldiers stationed here, it became one of the most difficult areas to control. The region's firm support of the revolution, its difficult terrain, propensity for torrential rains, along

${ }^{162}$ Silbey, A War of Frontier and Empire, 2008, 194-96. 
with the related mosquitoes and the diseases they carried, all combined to fight against American pacification efforts. ${ }^{163}$

\section{BELL'S WAR}

To finally end the war here Chaffee selected James Franklin Bell and appointed him commander of the Third Separate Brigade. He stepped into command of the province with the atmosphere of frustration and reprisal on many Americans minds. Bell had recently been the Provost General of Manila and before that commanded the 36th U.S. Volunteer Infantry Regiment in Pampanga Province, north of Manila. His plan for Batangas was a blend of paternal humanitarianism and hard war philosophy learned from the numerous campaigns that he had fought so far. He recognized the need to protect those Filipinos loyal to American rule, but would approve a broad range of reprisals for those who were not. Bell's campaign in Batangas was consistent with tactics American forces had already employed in the Philippines, but his implementation would be a step further and eventually became the most thorough pacification campaign of the entire war. $^{164}$

Bell had been an energetic and aggressive officer throughout his service in the Philippines. As a Colonel of the $36^{\text {th }}$ U.S. Volunteer Infantry, he had been awarded the Congressional Medal of Honor for charging seven insurgents armed only with his pistol and forcing three to surrender. The action had begun because Bell and his men could hear heavy firing coming from a nearby town. Bell, along with some of his officers and

\footnotetext{
${ }^{163}$ Brian McAllister Linn, The U.S. Army and Counterinsurgency in the Philippine War, 1899-1902, First Edition (Chapel Hill: The University of North Carolina Press, 2000), 120-21.

${ }^{164}$ Linn, The Philippine War, 1899-1902, 2000, 300-301.
} 
scouts left ahead of the regiment to investigate, with the remainder of the regiment following behind. Bell and the men with him encountered the enemy patrol and captured all seven, and although two of the insurgents had been wounded, no one on either side was killed in the close range exchange of fire. Throughout the record of the $36^{\text {th }}$ Infantry Bell appears leading patrols and attacks on enemy positions. Even at these earlier stages of the war, Bell recognized the need to seize arms and capture insurgents, which would become key during his command in Batangas. ${ }^{165}$

Bell was also widely recognized as the right officer for the job. Taft and others praised Bell's previous success, and they also recognized the nature of Bell's coming campaign. One member of the Philippine Commission wrote,

"He is sent to Batangas to make peace, and he proposes to do it even if the peace which he establishes must be the peace of desolation. He seemed to be in a somewhat reflective and subdued frame of mind in the presence of an undertaking which may bring destruction to a once rich province and great suffering to a large body of people. While the task is not of his choosing, it is clear that although he may expect to be vilified and have to bear the responsibility of action in many cases which he cannot control he seemed to have a deep determination to carry out his orders and to end rebellion in Batangas." 166

For his campaign in Batangas, Bell commanded the entire Third Separate Brigade. The brigade consisted of 7,600 soldiers in two cavalry regiments and six infantry regiments. In addition, Bell had nearly 700 Filipinos attached to the brigade as native scouts. Bell's plans centered on controlling the population and the supplies

\footnotetext{
${ }^{165}$ Grove, Record of Operations of Thirty-Sixth Infantry, U.S. Volunteers, from Its Organization in July, 1899 to Date of Muster out in March, 1901, 11.

${ }^{166}$ Glenn Anthony May, Battle for Batangas: A Philippine Province at War, First Edition (New Haven: Yale University Press, 1991), 246-48.
} 
available to the insurgents, particularly weapons, and on separating the insurgents from their supporters in the local population. ${ }^{167}$

Opposing Bell was one of the best equipped and determined bands of insurgents. It had been led by General Miguel Malvar in Batangas province and General Juan Cailles in Laguna province since Aguinaldo's proclamation of guerrilla war. Cailles had been the commander that had handed the Americans their defeat at Matibac, second only to Balangiga in the scale of American losses and one of the only instances in which Filipino forces withstood an American assault. Although Cailles was instrumental in building the insurgent network in this region by the summer of 1901 he had decided to surrender, following Aguinaldo's capture that spring. Despite Cailles and Aguinaldo's surrender, and increasing pressure from former insurgents to accept American rule Malvar was determined to continue his resistance. ${ }^{168}$

Malvar proved to be one of the best leaders the Filipinos fielded throughout the war. His leadership was no small part in why the resistance continued for so long in the region. Malvar was a wealthy native of Batangas who had begun organizing revolutionary bands to fight the Spanish in 1896 and was known for his desire for complete independence. Thanks to the efforts of Malvar and Cailles the Filipino resistance in these provinces was among the best organized of the war. Malvar realized that he could not win by trying to outfight the American Army and instead concentrated his efforts on keeping control over the local population to deny the region to his opponents. He relied on a strong network of local elites to lead the resistance and was

\footnotetext{
${ }^{167}$ Linn, The U.S. Army and Counterinsurgency in the Philippine War, 1899-1902, 2000, 152.

${ }^{168}$ Linn, The Philippine War, 1899-1902, 2000, 296-97.
} 
willing to resort to force to keep civilians from switching sides. At least at the beginning of the guerrilla war, the insurgency in Batangas had more uniform support from the local populace than in many other regions. In many areas where the resistance struggled to maintain the support of the residents, insurrectos in the second district could count on more popular support based on the ethnic and cultural ties as well as the fact that the region had been a homeland for the resistance since the original revolt against Spain. ${ }^{169}$

As American strategy in the Philippines shifted from Benevolent Assimilation to counter-insurgency, American commanders began to realize they needed to attack the means of insurgents to wage war, and not their motivations. If pacification had focused on showing Filipinos what American rule could do to benefit them, then the turn to counter-insurgency embodied in Bell expressed what awaited them if the insurgents would not surrender. From the start of his campaign, Bell understood his mission as bringing about peace through a hard war. ${ }^{170}$

The failure of the campaigns of attraction had been that they did not eliminate the insurgent presence, and there would always be die hard fighters that would go on fighting to hinder American progress. Leaders like Malvar sought independence and would keep the war going as long as they were able. Bell understood that and attempted to attack their means to keep fighting. Even the staunchest freedom fighters could not fight without food, money, and arms.

Once the Americans realized that their policy of attraction had allowed the insurgency to gain control of the civilian population, at least in those areas in which the

\footnotetext{
${ }^{169}$ Linn, The U.S. Army and Counterinsurgency in the Philippine War, 1899-1902, 2000, 129-30.

${ }^{170}$ Gates, Schoolbooks and Krags, 1973, 260.
} 
insurgency was active, they also realized that no amount of public works projects could get the civilians to change sides. The Americans relied on the civilian population for intelligence and even manpower, and the insurgents needed them as their only real source of supplies. If one side could isolate the civilians from the other, they could effectively control a town or province, even if a large enemy force was present. For insurgents, they isolated the civilians through intimidation and their shadow government. For Americans, they did so by offering civilians protection, aid, or even threats. Bell understood this dynamic as well as any American officer in the entire war. His campaign to end the insurgency in Southern Luzon would be the most complete and efficient campaign of the Philippine-American War. ${ }^{171}$

The American policies in the Philippines had always assumed the full right of America to control the islands. In the mindset of the period America had gained the islands legally through its peace treaty with Spain and America was the lawful authority of the land. McKinley's administration had delayed in coming up with a cohesive policy towards the Philippines, and in some ways, the Army had defaulted into its role as civil administrators and counter-guerrilla fighters. ${ }^{172}$

Bell's view on the United States' right to be in the islands followed a similar logic. When he assumed command of the Third Separate Brigade he argued as much in his speech to his officers. Bell's position was that Americans were the rightful rulers of the Philippines and that the resistance to American rule was an insurrection. Because an insurrection opposed lawful American rule, then the U.S. Army could implement

${ }^{171}$ Linn, The U.S. Army and Counterinsurgency in the Philippine War, 1899-1902, 2000, 159-60.

${ }^{172}$ Gates, Schoolbooks and Krags, 1973, 17. 
measures to defeat it as outlined by General Orders 100. Bell's tenure as commander was not the first time the American military had made use of General Orders 100 during the war, but Bell frequently cited sections of it in his orders to his command. Bell went so far as to issue a copy of General Orders 100 to every officer in his brigade. ${ }^{173}$

When Bell spoke to his officers, he explained that he planned to make the insurgents want peace. Bell viewed Batangas as the center of the insurgency. He clearly outlined a plan to root out anyone that was helping the insurgents, in particular among the Filipino elite. Bell suspected that the insurgency in the area under his command relied on the support of local landowners and officials who benefited from continuing the rebellion. By subjecting those who supported the insurgency to hardship and breaking their contact with the insurgent forces Bell believed he could bring about an end to the war. He understood his mission in Batangas to be forcing the insurgents to surrender and bring about peace even if it meant hardship for the civilians and in fact by waging a hard war could achieve peace more quickly. ${ }^{174}$

Following his speech to his officers, Bell began issuing telegraphic circulars to his command. Bell distributed the circulars to all the stations under his command, and he wrote them as standing orders for the duration of the campaign. Bell's circulars outlined the ways in which he intended to bring an end to the insurgency on an almost point by point basis. If his speech to his officers was a summation of his philosophy, then his

\footnotetext{
${ }^{173}$ J. Franklin Bell and M. F Davis, Telegraphic Circulars and General Orders Regulating Campaign against Insurgents and Proclamations and Circular Letters Relating to Reconstruction after Close of War in the Provinces of Batangas, Laguna and Mindoro, Philippine Islands (Batangas, Batangas Province, P.I.: Headquartes, Third Separate Brigade, 1902), I-VIII.

${ }^{174}$ Ibid., V-VIII.
} 
telegraphic circulars became the practical embodiment, although they often included further justifications for the actions that Bell took.

Bell's orders can be broken down into a few categories. Some dealt with specific tactics to combat the insurgency and destroy their means to wage war. Other circulars dealt with policing the garrisoned areas, mainly by targeting what Bell thought was the biggest source of insurgent support, the wealthy citizens, and officials who had not demonstrated loyalty to the Americans. In more mundane circulars Bell issued reminders to his men to be vigilant or not to abuse the leeway he had given them in hunting insurgents. Bell's campaign began shortly after, and was concurrent with, Smith's excesses on Samar, and Bell had previously acknowledged the extremes to which his men had gone to gain information from insurgents. He certainly had some reason to worry about further incidents causing problems in his command. ${ }^{175}$

The final category which encompasses a significant amount of Bell's circulars deals with food. Bell saw the food supply in the provinces under his control as part of the means of the insurgents to wage war. If he could attack and destroy their food supply, he could bring a quicker end to the conflict. In essence, siege out the entire region to starve the insurgency into submission. It was not his only tactic, but it played a role in his overall plan to end the insurgency. As militarily sound as this might have been, it soon caused problems for the civilian population, and many of his orders reflect a growing food shortage because of the American campaign.

${ }^{175}$ Linn, The Philippine War, 1899-1902, 2000, 224. 
Before Bell could secure the insurgent's supply caches and food, he had to isolate their supporters. The keystone to Bell's plan for Southern Luzon and the most controversial of his orders was Circular Number Two. In it, Bell officially ordered all of the civilians in the area of the Third Brigade to be relocated into American-controlled towns. ${ }^{176}$ From his second circular dated December 8th, 1901,

"In order to put an end to enforced contributions, now levied by insurgents upon the inhabitants of sparsely settled an outlying barrios and districts, by means of intimidation and assassination, commanding officers of all towns now existing in the provinces of Batangas and Laguna, including those at which no garrison is stationed at present, will immediately specify and establish plainly marked limited surrounding each town bounding a zone within which it may be practicable, with an average size garrison, to exercise supervision over and furnish protection to inhabitants (who desire to be peaceful) against the depredations of armed insurgents. These limits may include the barrios which exist sufficiently near the town to be given protection and supervision by the garrison and should include some ground on which livestock can graze, but so situated that it can be patrolled and watched. All ungarrisoned towns will be garrisoned as soon as troops become available. Commanding officers will also see that orders are at once given and distributed to all the inhabitants within the jurisdiction of town over which they exercise supervision, informing them of the danger of remaining outside of these limits and that unless they move by December 25th from outlying barrios and districts with all their movable food supplies, including rice, palay, chickens, livestock, etc., to within the limits of the zone established at their own or nearest town, their property (found outside of said zone at said date) will become liable to confiscation or destruction." 177

This second circular was Bell's clear message on how he intended to wage the coming campaign. The order laid out how his soldiers would separate friend and foe.

\footnotetext{
${ }^{176}$ Ibid., 302 .

${ }^{177}$ Bell and Davis, Telegraphic Circulars and General Orders Regulating Campaign against Insurgents and Proclamations and Circular Letters Relating to Reconstruction after Close of War in the Provinces of Batangas, Laguna and Mindoro, Philippine Islands, 1.
} 
Each town in the province was turned into a fortified garrison with clear limits that established an American zone of control around the given town. Americans forced the Filipinos to move into these garrisons or "reconcentration zones." Any person that stayed outside the zones would be in danger, and any property could be seized or destroyed.

This tactic was not without precedent, both by American troops, and other colonial powers as well. The British had built concentration camps during the AngloBoer War, and the Spanish had used them Cuba. ${ }^{178}$ The term carries more weight to a post-World War Two audience, a more fitting term from modern usage might be internment camps. Whatever the name, the American public reviled the camps. Their use by Spain had been widely denounced in the United States, and the Spanish General Weyler had received his nickname of "Butcher Weyler" in part for his use of reconcentration camps. Chaffee considered Bell's policy so potentially damaging that he asked for the letter about it to Secretary Root to be destroyed. ${ }^{179}$ When the American public found out about their use in the Philippines, there were loud outcries and observers noted the similarities between Bell's actions and Weyler's policies in Cuba. ${ }^{180}$

As many as 170,000 civilians may have died in Weyler's camps. Weyler, who had admired General Sherman, dismissed the idea that his camps were unusually harsh, and he used the American Civil War as an example. When asked by Fitzhugh Lee about his camps, Weyler responded, "Everything is fair in war." ${ }^{181}$ A Spanish ambassador to Washington cited Sheridan's and Sherman's campaigns in the Civil War, and the

\footnotetext{
${ }^{178}$ May, Battle for Batangas, 1991, 242.

${ }^{179}$ Linn, The Philippine War, 1899-1902, 2000, 303.

${ }^{180}$ Boot, The Savage Wars of Peace, 2014, 124.

${ }^{181}$ Matthew Carr, Sherman's Ghosts: Soldiers, Civilians, and the American Way of War (New York: The New Press, 2015), 192-93.
} 
"Burning of entire cities, the ruin and devastation of immense and most fertile regions, to the annihilation of all goods of the adversary." ${ }^{182}$

American garrisons formed the camps from existing towns and garrisons. Soldiers forced outlying civilians to move into towns under American control. Bell allowed garrison commanders to implement the order to their discretion, and there was variance from town to town, often based on the capability of the garrison and the history of that town. In quiet areas of the province that had seen limited or even no fighting the Filipinos had much more freedom to be out of the camps during the day. Towns with particularly small garrisons, often the same places as the previous example, were unofficially allowed to go without rounding up all the inhabitants from the surrounding countryside and continue their duties as before. ${ }^{183}$

Despite these exceptions, civilians tightly packed the zones with simple shacks hastily built to accommodate the massive influx of residents. This order ostensibly protected inhabitants from insurgent forces, but it had other desired outcomes as well. With it, Bell created a clear line of friend or foe for his soldiers. American soldiers measured the limits of the zones in hundreds of yards, effectively rifle range, and labeled these lines as a "dead line."184 Anyone found beyond the line was subject to be arrested or even shot without question. People within the zones were at least publicly not insurgents and guaranteed protection from insurgent retaliation. To American soldiers,

\footnotetext{
182 Ibid., 194.

${ }^{183}$ Linn, The U.S. Army and Counterinsurgency in the Philippine War, 1899-1902, 2000, 154.

${ }^{184}$ Linn, The Philippine War, 1899-1902, 2000, 303.
} 
anyone that remained outside the zones was an insurgent or potentially supporting them. $^{185}$

Bell's tactics, used by other American officers in Samar has parallels in modern wars as well, just as his hard war has parallels to previous conflicts. It was to be a "war among the people", much like the ones the French experienced in Indochina and Algeria, or the British in Malaysia. If NATO had a "shape, clear, hold, and build" formula to fighting in Afghanistan ${ }^{186}$, then Bell's slogan could have been "shape, clear, hold, and burn."

Bell's separation of the population and insurgents created kinds of safe zones for his soldiers where they could operate in relative security in their garrisons and affect control over the civilian population. This tactic was not without precedent and it has been used since. The British used concentration camps against the Boers, and during the Vietnam War, American and South Vietnamese forces relocated civilians into protected villages in an attempt to separate enemy combatants from the population. ${ }^{187}$

In addition to making the rules of engagement outside the garrisons simpler, the order also moved the insurgent supply base out of their control. The insurgents had been living off the supplies they could get from locals and moving the locals inside American controlled areas meant that Bell now controlled the main food supply. Americans destroyed any supplies that they did not bring inside the zones, leaving the insurgents to

\footnotetext{
${ }^{185}$ May, Battle for Batangas, 1991, 249-51.

${ }^{186}$ Understanding Counterinsurgency: Doctrine, Operations, and Challenges, First Edition (Milton Park, Abingdon, Oxon, England ; New York: Routledge, 2010), 12-13.

${ }^{187}$ Ibid., 76.
} 
live off a land that been wiped clean of supplies. The American troops in Batangas began a thorough effort to destroy anything that was left in the countryside that could be used by insurgents. Filipinos left buildings, crops, livestock, and whatever other supplies they could not bring. Soldiers gathered up and burned whatever was left in the countryside. In one of the first expeditions of the new year, which lasted just over a week, Bell's men destroyed 1400 tons of rice and palay, killed 200 carabaos, 800 cattle, 680 horses, and burned 6,000 homes. ${ }^{188}$

This aggressive campaign later caused problems for the population of Batangas. As Bell's command of the province went on, the civilian population began to experience major food shortages. Filipinos attempted to grow crops in and around the now crowded towns, but could not provide enough food to replace all that the Americans destroyed. Despite its negative impact on civilians, it proved effective against the insurgents, for without farmers to aid them, they had to forage what little food they could find, leaving them malnourished and having to spend much of their time searching for food. ${ }^{189}$

The policy offered another benefit for Americans. It allowed American troops to better protect Filipinos who had proved their loyalty to the American government. Insurgents had targeted not just American troops, but also people suspected of working with the Americans. The inability to protect loyal Filipinos created a problem, and Americans had to show that they could enforce their rule and protect anyone willing to

\footnotetext{
${ }^{188}$ May, Battle for Batangas, 1991, 254-55.

${ }^{189}$ Ibid., 261-64.
} 
declare loyalty to the United States. Bell sought to remove the fear of reprisal from Filipino civilians so that they would work with the Americans. ${ }^{190}$

Conditions in the camps varied in some degree from town to town. In some, farmers could leave to harvest crops, others had much tighter control, and farming was limited plots of land to grow crops within the zones. The civilian population in the area under bell's command was around 300,000. One town grew from 5,000 to 30,000, the city of Lipa held 43,000. These dense populations became susceptible to disease, which was exacerbated by major food shortages brought on by the destruction of large stores of food by American troops. Between January and May, 1902 over 11,000 Filipinos died in Batangas. While these deaths were not the direct result of American action, Bell's policies certainly contributed to them. ${ }^{191}$

In Circular Number Three Bell blamed the population of Batangas for the continuation of the conflict. He believed that most of the Filipinos supported the insurrection while claiming to want peace. He was enacting his orders to, "Make the people want peace and want it badly." ${ }^{192}$ This circular was a clear statement about his philosophy of a hard war to bring about peace. He went on to write, "A short and severe war creates in the aggregate less loss and suffering than benevolent war indefinitely prolonged." 193

\footnotetext{
${ }^{190}$ Bell and Davis, Telegraphic Circulars and General Orders Regulating Campaign against Insurgents and Proclamations and Circular Letters Relating to Reconstruction after Close of War in the Provinces of Batangas, Laguna and Mindoro, Philippine Islands, VIII.

${ }^{191}$ May, Battle for Batangas, 1991, 264-67.

${ }^{192}$ Bell and Davis, Telegraphic Circulars and General Orders Regulating Campaign against Insurgents and Proclamations and Circular Letters Relating to Reconstruction after Close of War in the Provinces of Batangas, Laguna and Mindoro, Philippine Islands, 2.

${ }^{193}$ Ibid.
} 
Circular Three was one of the longest Bell issued and goes on to detail the way in which Bell planned to break up the insurgent network. He told his men to make use of a network spies, loyal police, native scouts and provost courts to break up the insurgent network and to put pressure on the wealthy Filipinos and officials suspected of aiding the insurgency. ${ }^{194}$

Although Circular Four has received less attention than his circular detailing reconcentration, it shows the extreme limit to which Bell was willing to go to prosecute this war. In it, Bell laid out a list of charges against the Filipino combatants and alleged crimes against the laws of war and the U.S. government, specifically in violation of G.O. 100. The crimes included assassination, killing American wounded, booby traps, intimidation of civilians, violating pardons, and treason. Because of these violations, Bell authorized executions in retaliation for any assassination against an American or loyal Filipino. Any execution was to be specifically for retaliating against an assassination by insurgents and was conducted by picking a prisoner by lot, preferably one from the town where an assassination had happened. ${ }^{195}$

In the following circular, Bell authorized another form of retaliation. Station commanders could burn down Filipino property equivalent to whatever the insurgents destroyed of American property. They were encouraged to burn down property that belonged to Filipino officials that Americans suspected of aiding the insurgents. Bell specifically recommended numbering the telegraph poles in each district and assigning

\footnotetext{
194 Ibid., 4-5.

${ }^{195}$ Ibid., 8-9.
} 
each one to a Filipino. If insurgents destroyed a telegraph pole, it would be the responsibility of that individual to repair it. ${ }^{196}$

Insurgents had made use of terror and intimidation to keep civilians loyal that included public assassinations of those known to support the Americans. In the war, both sides showed a willingness to resort to intimidation and terror as a means of coercion. Both sides needed civilian support and used force to gain it when other means failed. ${ }^{197}$

Bell also reinstated a Spanish law requiring labor as a tax imposed on the local population. Filipinos could also pay three pesos to get out of the labor requirement, but if they could not then they were required to work for the Americans to repair roads, bridges, and telegraph lines. Bell eventually authorized the money raised from this tax to pay for food and used the labor to repair roads. He restricted movement and trade between towns. Bell also issued an order to disarm the native police, which was separate from the native auxiliary scouts the U.S. Army had been using effectively. Bell suspected the police in many towns of having ties to the insurgency and suspected them of smuggling arms and money to Malvar's forces. ${ }^{198}$

Bell made arms a primary objective of his campaign and authorized his men to pay up to thirty pesos for a serviceable firearm. At the same time, the reward for an officer's capture was only five or ten pesos depending on their rank. Later on, Bell reminded his men that they should take any weapon even it was not serviceable by the

\footnotetext{
196 Ibid., 9.

${ }^{197}$ Linn, The U.S. Army and Counterinsurgency in the Philippine War, 1899-1902, 2000, 153.

${ }^{198}$ Bell and Davis, Telegraphic Circulars and General Orders Regulating Campaign against Insurgents and Proclamations and Circular Letters Relating to Reconstruction after Close of War in the Provinces of Batangas, Laguna and Mindoro, Philippine Islands, 6,13-17.
} 
army's standards. He went so far as to encourage his men to pay up to twenty pesos for shotguns and revolvers, weapons which were not commonly used against American forces, as a way to get more Filipinos to turn in firearms. The emphasis had been a part of Bell's time as a regimental commander and had been a major objective for American forces throughout the war. Bell also ordered that all native horses were to be turned in and accounted for and that even his men could not use them unless authorized. He ordered Filipinos to turn in their bolos and knives, except for a few more peaceful areas where they could have them dulled by a blacksmith instead. These were all means with which an insurgent could fight back against the Americans and Bell placed a clear priority on capturing as many weapons as he could. ${ }^{199}$

Throughout Bell's circulars, he issued general reminders to his troops and warnings to the Filipinos. While these are somewhat less specific, they continue to show Bell's intent and reasoning. He reminded his men to be vigilant and always armed, and he wrote that he expected his orders would cause a strong response. He was obviously aware of the potential for another Balangiga, even going so far as to cite that attack specifically as a warning to his men. He wanted to avoid any opportunity for the insurgency to gain a victory. He also warned the Filipinos that if a town did rise up against its garrison that it would be completely burned. The warnings to his men and the Filipinos mimic the attack at Balangiga for a reason, the American's there were caught without weapons and the retaliatory burning the town was well known by this point. ${ }^{200}$

\footnotetext{
199 Ibid., 20-21.

${ }^{200}$ Ibid., 3, 13.
} 
In all of his circulars, Bell assumed the guilt of the Filipinos of violating G.O. 100 and that they all likely had supported the insurgency to some degree during the war. Therefore all Filipinos bore at least some of the responsibility for what was now happening. There was clearly an impact on all of the Filipinos within Bell's command. Bell's campaign severely compounded existing food shortages. Bell recognized the public health problem his campaign created and began a public vaccination campaign that eventually vaccinated nearly the entire population of Batangas. ${ }^{201}$ Bell also issued some of his circulars in direct response to the food shortages and sought to import rice to help alleviate the humanitarian crisis. Bell eventually allowed Filipinos to accompany American patrols so they could find and bring back food for themselves. ${ }^{202}$

Bell's campaign in Batangas was not just limited to concentration and martial law. He also ordered his commanders to send out patrols constantly searching for insurgent bands. Bell's forces pursued Malvar's bands far into insurgent territory. By late February what remained of Malvar's army was close to capitulation with only a few bands left in the field along with Malvar himself. To speed up to the defeat of insurgent forces, Americans also began to put captured insurgents on trial for violations of G.O. 100 unless they gave the Americans useful service or intelligence, which usually resulted in the capture of more insurgents, weapons, or supplies. ${ }^{203}$

\footnotetext{
${ }^{201}$ Linn, The U.S. Army and Counterinsurgency in the Philippine War, 1899-1902, 2000, 154.

${ }^{202}$ Bell and Davis, Telegraphic Circulars and General Orders Regulating Campaign against Insurgents and Proclamations and Circular Letters Relating to Reconstruction after Close of War in the Provinces of Batangas, Laguna and Mindoro, Philippine Islands, 14-17, 21, 26-27.

${ }^{203}$ May, Battle for Batangas, 1991, 260-62.
} 
Bell clearly articulated his idea of a hard war in his many orders. In his early orders, Bell stated his desire to bring about peace and to accomplish that he planned to make continued resistance unbearable for the remaining insurgents. His later orders contain many reminders to his soldiers to show restraint and not bring undue hardship on the civilians around them. Despite his softening and realization of the problems that this campaign had created, Bell remained committed to bringing about peace through a hard war and his methods worked. Malvar and his remaining men surrendered at the beginning of April. Malvar and his officers attributed the effectiveness of Bell's campaign to the reconcentration zones and Bell's persistent pursuit of the insurgents. One officer claimed that they could have kept fighting for three more years without reconcentration. Malvar himself said at the time of his surrender that "I found myself without a single gun or clerk...all my staff officers had already fallen into the hands of the Americans." 204

Bell took command in December 1901. His first circulars were dated in midDecember, and by mid-April 1902 he had accepted Malvar's surrender. It took him four months to reduce one of the last strongholds of insurgent activity in the Philippines. With Samar before it and now Batangas and the other provinces of Southern Luzon pacified, the U.S. was able to claim that the war was over and in July of 1902 President Roosevelt declared the war won. Sporadic fighting and even major campaigns continued long after Roosevelt's declaration. However, the war against anything that resembled a Filipino national movement was over.

\footnotetext{
${ }^{204}$ Linn, The Philippine War, 1899-1902, 2000, 304.
} 
Bell's campaign had succeeded in bringing an end to resistance in Batangas by enacting a hard war on the Filipino insurgents. He succeeded where commanders for two years had failed to end the insurgency. He emerged from the war as one of the premier counter-insurgency officers in the Army. His campaign had caused great hardship for the civilians that lived through it and contributed to a dire humanitarian crisis both during and afterward. Despite this, his campaign still stands as a success over an indigenous guerrilla army. Bell's circulars lay out a comprehensive counter-insurgency plan that brought about an end to the war. His plan was based on his experience as well as the previous half century of the U.S. Army's campaigns and shared strategies with America's European rivals. Because of the nature of the campaign and the Philippine-American War, it has largely been forgotten or treated as a sideshow to American military history. However, the Philippine-American War is linked to the long story of the U.S. Army, most notably through Bell and the hard war that he waged in the spring of 1902. 


\section{CONCLUSION}

In Cheyenne, Wyoming, at the Francis E. Warren Air Force Base, there is a reminder of the Philippine-American War, two of the Balangiga Bells. When American troops returned to Balangiga following the Filipino attack, they sacked the town and took the church bells as a prize. They stayed with the $9^{\text {th }}$ Infantry Regiment for a time and one of the three bells is still with the unit at its base in South Korea. The remaining two were brought back to then Fort D.A. Russell by the $11^{\text {th }}$ Infantry Regiment which had replaced the $9^{\text {th }}$ Infantry Regiment in garrisoning Balangiga. Officials from the Philippines have asked for the bells to be returned on several occasions. Other church bells from the war have been returned, but so far the Balangiga Bells have remained in U.S. hands. ${ }^{205}$ The bells are a little-known reminder of the war in the same way that the war itself is frequently a footnote to the Spanish-American War.

But the Philippine-American war, regardless of how well it is remembered, is an important link in the history of the American way of war. As a conflict it shares many of the traits and influences of those wars which historians debate more often. Just as the Union entered the Civil War with a policy of reconciliation, the American government began the Philippine war with a "policy of attraction." While not completely alike, they

\footnotetext{
${ }^{205}$ Edgar Allan M. Sembrano (contributor), "Return of San Pedro Bell Brings Hope for Balangiga Bells' Repatriation,” June 6, 2016.
} 
shared similar qualities in that enemy noncombatants were off limits, and their way of life was to be left as undisturbed as possible in order to win them over. For the American South in the Civil War, there were only limited initial incursions that sought to avoid large scale destruction of property and economy. The harshest measures of G.O. 100, adopted during the war for the very situation the Union encountered - fighting among civilians in hostile territory - were not carried out to the fullest. In the Philippines, the American policy of attraction in some ways went even further initially to avoid alienating the Filipino population. The U.S. government actively tried to win popular support among Filipinos through government programs and construction efforts.

Even when the war turned to stern measures, the U.S. showed some restraint. Sherman's March was limited in destruction to its immediate area; likewise, Sheridan's campaign through the Shenandoah Valley. Neither Sherman or Sheridan resorted to wanton killing and they focused the destruction of goods on things useful to the Southern war effort, which provided some measure of restraint to their raids.

When Bell began his own hard war, he imposed harsh measures on the Filipino civilians that went beyond tactics employed during the Civil War. Two examples were the large-scale relocation of the population and what amounted to free fire zones outside of American garrisons. Even then, Bell showed at least some restraint, making efforts to keep the population under his control fed and supplied. While the population suffered from disease and many died, the American forces were not carrying out a program of execution. When Bell's orders brought about victory, civilians were allowed to return home and rebuild. It may seem like a narrow distinction, but it is an important one. Bell's war was a hard war, not a war of annihilation. 
At the end of each conflict, civilian life was largely intact, although the loss of life from famine was significant as a result of Bell's campaign. In both the American South and Batangas civilians lost goods and property on a large scale. At the end of the conflict, they had the chance to resume their lives and in some cases emerged largely unscathed.

His orders were designed to end the enemy's capability to resist, not to bring about full-scale destruction. It may be little comfort to those that suffered, but Bell's harsh orders combined with serious efforts at restraint are the hallmarks of a hard war and distinct from a war of annihilation or total war. It was not the extirpative war of colonial Americans against Native peoples, nor was it a limited war in which non-combatants were off limits. Like others before and after, Bell's commands showed willingness to use military superiority to destroy the enemy's capability to fight by exposing noncombatants to danger and deprivation in order to end the conflict.

The American pacification campaign and Bell's campaign in Batangas were ultimately fought as hard wars. There are two main caveats to that assessment. The first is that is that the war was frequently balanced with the Army's social programs, such as school construction and public health programs. ${ }^{206}$ The second that the war was locally fought with widespread differences. Two garrisons within just Bell's area of command may have carried out the war quite differently. Bell's orders demonstrate that he granted his officers considerable leeway, especially in those areas without significant conflict. However, even with these caveats, the essence of a hard war was still there. Bell's

\footnotetext{
${ }^{206}$ Gates, Schoolbooks and Krags, 1973.
} 
campaign was not the only instance, but perhaps the clearest example. Just as Sherman was willing to burn and destroy whatever might aid the Confederacy, Bell was willing to burn and destroy whatever might aid the insurgents and to separate them from the population that supported them. Bell's war was one of hardship to end the war. He saw hard war as the quickest path to peace, a peace that would only incorporate his enemies once they capitulated.

The Philippine-American War was a counter-insurgency war. These kinds of conflicts have dominated recent American military history. Twentieth and now twentyfirst-century armies have been plagued by the problem of counter-insurgency wars. ${ }^{207}$ Those conflicts are often frustrating and seemingly unwinnable. Yet, as Max Boot claims, the Philippine-American War was "one of the most successful counterinsurgencies waged by a Western army in modern times." ${ }^{208}$ The U.S. Army, through commanders like Bell, was willing to resort to hard war to achieve that success.

Yet in recent insurgencies like Iraq and Afghanistan, the U.S. has not resorted to a hard war. For much of those conflicts, the U.S. military kept clear rules of engagement in place in order to protect non-combatants. Even though these twenty-first ${ }^{\text {st }}$ century wars share similarities to the Philippine-American War, the use of small local garrisons to control as much territory as possible, an influx of soldiers to actively patrol and maintain supply lines, and the uncertainty about who exactly was an enemy combatant, there were

\footnotetext{
207 Understanding Counterinsurgency, 1-8.

${ }^{208}$ Boot, The Savage Wars of Peace, 2014, 128.
} 
still clear limits. American and Coalition forces did not resort to targeting noncombatants as a strategy to win the war.

Perhaps the best examples of when U.S. forces were willing to cross that threshold is to look to wars prior to the Philippine-American War, such as the campaigns against Native Americans and the Civil War. Bell's campaign is in essence another example of the kind of warfare that Grenier explored in his book on Colonial and Early American warfare against Native Americans. ${ }^{209}$ While Bell certainly did not aim to annihilate the Filipino population, as English settlers were when dealing with Native Americans, his tactics share more than just common themes with the extirpative wars waged by colonists in early North America. In fact, after examining the PhilippineAmerican war in more detail, we have to accept that hard war is not the exception but the main undercurrent that links conflicts from the early colonies until at least Bell's campaign in the Philippine-American War, and a number of recent U.S. conflicts in the twentieth and twenty-first century.

Bell's explanation of hard war through his telegraphic circulars match the tactics that Sherman and Sheridan employed and embraced. Despite the Army's efforts during the nineteenth century to focus and prepare for an outward opponent - a possible British or French invasion - it spent most of its time fighting what were then called small or minor wars; what we would now call counter-insurgencies or unconventional wars. After the War of 1812, the threat of European invasion never materialized again in the United States. It served only as a theoretical exercise and the harbor forts that were built to

${ }^{209}$ Grenier, The First Way of War. 
counter such an invasion saw their only combat during the Civil War. Instead, the U.S. Army primarily fought unconventional wars at home and abroad. ${ }^{210}$

As a military force, the U.S. Army became quite adept at fighting small wars, and even during more conventional wars, it resorted to using the lessons learned from small wars against major opponents, as Sherman and Sheridan proved. Those campaigns were attacks on the opponent's ability to continue fighting by pressuring noncombatants, a hard war. They were larger in scale from the way of war practiced against Native Americans, but relatable. Bell's campaign in Batangas was not a leap or even an evolution of the concept; it was a way of war he and the U.S. Army knew how to fight and had long been fighting.

Bell was a career officer, a lieutenant only a few years before the outbreak of the Philippine-American war. When he was tasked with defeating a capable insurgent force, he resorted to a hard war. This strategy had begun with MacArthur and the intelligence victories that uncovered the revolutionary shadow government and it was carried to its fullest with Bell's campaign in Batangas. It was a key to U.S. victory in the Philippines, despite its toll on the Philippine population. As Bell and others saw it, this was the most expedient way to end the war. Harsh but short, to avoid a prolonged conflict. It was a way of war which showed up throughout American military history that would be recognizable to both Bell's predecessors and successors.

The Philippine-American War set the stage for many later American interventions throughout the twentieth century. While it was not the first time the United States had

\footnotetext{
${ }^{210}$ Linn, The Echo of Battle, 68-71.
} 
ventured overseas militarily, it was the largest by a wide margin to that date. Once the United States had exercised its imperial muscle it would do so again in Central and South America in the 1920s and 1930s. While covert government operations to topple rulers are somewhat removed from the Philippine-American War, it is impossible to ignore the similarities between the conflict and many of the later wars America would fight. From fortified villages in Vietnam to the remote outposts trying to catch up with under armed insurgents in Afghanistan, America fought these kinds of wars before. America has waged successful hard war for a long time, yet the modern attempts to fight insurgencies have resulted in frustration, even with major campaigns to win local support and separate the population from insurgents. The lesson from the Philippines is that America could win these wars, but with a hammer that might not have a suitable modern nail. 


\section{REFERENCES \\ ARCHIVAL SOURCES}

Bean, Richard, Papers. Filson Historical Society, Special Collections.

Bell, James Franklin, Papers. United States Army Heritage and Education Center, Archival Collections.

\section{NEWSPAPERS}

Edgar Allan M. Sembrano. "Return of San Pedro Bell Brings Hope for Balangiga Bells' Repatriation," Philippine Daily Inquirer, June 6, 2016.

Pincus, Walter “Fine Print: U.S. Can't Seem to Shake the 'Water Cure' as a Method of Interrogation.” Washington Post, May 1, 2014.

\section{PUBLISHED PRIMARY SOURCES}

American Art Association, and James Franklin Bell. The General Bell Collection: Arms and Weapons, Indian and Philippine Baskets, Blankets and Curios Collected by the Late James Franklin Bell, Major-General U. S. A. New York: Lent \& Graff Co., 1919.

Otis, Ewell. S. Report of Major General Otis on Military Operations and Civil Affairs in the Philippine Islands, 1899. Washington, Government Printing Office, 1899. 
Grove, William R. Record of Operations of Thirty-Sixth Infantry, U.S. Volunteers, from Its Organization in July, 1899 to Date of Muster out in March, 1901. [Place of publication not identified]: [publisher not identified], 1901.

Lieber, Francis Instructions for the Government of Armies of the United States in the Field. Washington, Government Printing Office, 1898.

Office, Oregon Adjutant-General's, and W. E. Finzer. The Official Records of the Oregon Volunteers in the Spanish War and Philippine Insurrection. W.H. Leeds, State Printer, 1902.

Root, Elihu, and United States. Elihu Root Collection of United States Documents Relating to the Philippine Islands. Washington, Government Pringting Office, 1902.

\section{U.S. MILITARY PUBLICATIONS}

Brost, Todd. "All Wars Are Local: Lessons from the Philippine Insurrection.” DTIC Document, 2009.

Carlson, Ted W. "The Philippine Insurrection: The U.S. Navy in a Military Operation Other Than War, 1899-1902.” DTIC Document, 2004.

Craig, James R. "A Federal Volunteer Regiment in the Philippine Insurrection: The History of the 32nd Infantry (United States Volunteers), 1899 to 1901.” DTIC Document, 2006.

Deady, Timothy K. "Lessons from a Successful Counterinsurgency: The Philippines, 1899-1902.” DTIC Document, 2005. 
Early, Gerald H. "The United States Army in the Philippine Insurrection, 1899-1902." DTIC Document, 1975.

Hogg, David R. “The Legal Use of Terror as a Weapon.” DTIC Document, 1992.

Ramsey III, Robert D. A Masterpiece of Counterguerrilla Warfare: BG J. Franklin Bell in the Philippines, 1901-1902. U.S. Government Printing Office, 2008.

"Savage Wars of Peace: Case Studies of Pacification in the Philippines, 19001902.” DTIC Document, 2007.

\section{SECONDARY SOURCES}

Anderson, Fred, and Andrew Cayton. The Dominion of War: Empire and Liberty in North America, 1500-2000. Reprint Edition. Penguin Books, 2005.

Arnold, James R. Jungle of Snakes: A Century of Counterinsurgency Warfare from the Philippines to Iraq. First Edition. New York: Bloomsbury Press, 2009.

Bain, David Haward. Sitting in Darkness: Americans in the Philippines. Boston: Houghton Mifflin, 1984.

Boot, Max. The Savage Wars of Peace: Small Wars and the Rise of American Power. Revised Edition. New York: Basic Books, 2014.

Carr, Matthew. Sherman's Ghosts: Soldiers, Civilians, and the American Way of War. New York: The New Press, 2015. 
Coffman, Edward M. The Regulars: The American Army, 1898-1941. London: Belknap Press, 2007.

Cosmas, Graham A. An Army for Empire: The United States Army in the SpanishAmerican War. First Edition. College Station: Texas A\&M University Press, 1998.

Cozzens, Peter. The Earth Is Weeping: The Epic Story of the Indian Wars for the American West. First Edition. New York: Knopf, 2016.

Eanes, Greg. The "Old Guard" in the Philippine War: A Combat Chronicle and Roster. Charleston, S.C.: Greg Eanes, 2013.

Faust, Karl Irving, and Peter MacQueen. Campaigning in the Philippines. Hicks-Judd Company, 1899.

Feuer, A. B. America at War: The Philippines, 1898-1913. Westport, Connecticut: Praeger, 2002.

Fisher, Louis. "Destruction of the Main (1898)." Washington, The Law Library of Congress, 2009.

Francisco, Luzviminda, Shirley Jenkins, Luis Taruc, Renato Constantino, Ramon Diokno, David Joel Steinberg, Claro M. Recto, Philip Shabecoff, and President Emilio Aguinaldo. The Philippines Reader: A History of Colonialism, Neocolonialism, Dictatorship, and Resistance. Edited by Stephen Rosskamm Shalom. First Edition. Boston: South End Press, 1999.

Freidal, Frank, and Mark Clodfelter. The Splendid Little War. Short Hills, NJ: Burford Books, 2002. 
Galula, David. Counter-Insurgency Warfare Theory and Practice. Second Printing Edition. Praeger, 1965.

Gates, John M. Schoolbooks and Krags: The United States Army in the Philippines, 1898-1902. First Edition. Westport, Connecticut: Praeger, 1973.

Gentry, John A. How Wars Are Won and Lost: Vulnerability and Military Power: Vulnerability and Military Power. ABC-CLIO, 2011.

Grenier, John. The First Way of War: American War Making on the Frontier, 1607-1814. First Edition. Cambridge: Cambridge University Press, 2008.

Grimsley, Mark. The Hard Hand of War: Union Military Policy Towards Southern Civilians, 1861-1865. Cambridge: Cambridge University Press, 1997.

Jones, Gregg. Honor in the Dust: Theodore Roosevelt, War in the Philippines, and the Rise and Fall of America's Imperial Dream. First Edition. New York: NAL, 2012.

Karnow, Stanley. In Our Image: America's Empire in the Philippines. New York, Random House, 1989.

Linn, Brian McAllister. The Echo of Battle: The Army's Way of War. Cambridge, Mass: Harvard University Press, 2007.

—. "The Long Twilight of the Frontier Army." The Western Historical Quarterly 27, no. 2 (1996): 141-67.

The Philippine War, 1899-1902. Lawrence: University Press of Kansas, 2000. 
- The U.S. Army and Counterinsurgency in the Philippine War, 1899-1902. First Edition. Chapel Hill: The University of North Carolina Press, 2000.

Markey, Joseph Ignacious. From Iowa to the Philippines; a History of Company M, FiftyFirst Iowa Infantry Volunteers. Red Oak, Iowa, 1900.

May, Glenn Anthony. Battle for Batangas: A Philippine Province at War. First edition. New Haven: Yale University Press, 1991.

Miller, Stuart Creighton. Benevolent Assimilation: The American Conquest of the Philippines, 1899-1903. New Haven: Yale University Press, 1984.

Nagl, John A. Learning to Eat Soup with a Knife: Counterinsurgency Lessons from Malaya and Vietnam. First Edition. Chicago: The University of Chicago Press, 2005.

Poyer, Joe. The American Krag Rifle and Carbine. Edited by Craig Riesch. Second Edition. Tustin, California: North Cape Publications, 2007.

Rid, Thomas. Understanding Counterinsurgency: Doctrine, Operations, and Challenges. First Edition. New York: Routledge, 2010.

Silbey, David J. A War of Frontier and Empire: The Philippine-American War, 18991902. First Edition. New York: Hill and Wang, 2008.

Silverman, David J. Thundersticks: Firearms and the Violent Transformation of Native America. Cambridge, Massachusetts: Harvard University Press, 2016. 
Storey, Moorfield, Julian Codman, and YA Pamphlet Collection (Library of Congress) DLC. Secretary Root's Record. "Marked Severities” in Philippine Warfare. An Analysis of the Law and Facts Bearing on the Action and Utterances of President Roosevelt and Secretary Root. Boston, G.H. Ellis Co., Printers, 1902.

Trinquier, Roger. Modern Warfare: A French View of Counterinsurgency. Annotated Edition. Westport, Connecticut: Praeger, 2006.

Twain, Mark. Mark Twain's Weapons of Satire : Anti-Imperialist Writings on the Philippine-American War. Edited by Jim Zwick. Syracuse, N.Y: Syracuse University Press, 1992.

Utley, Robert M., and Wilcomb E. Washburn. The American Heritage History of the Indian Wars. First Edition. New York: Bonanza Books, 1982.

Weber, William. With the Thirtieth Infantry United States Volunteers, 1899-1900-1901. Carthagena, Ohio: The Author, 1957.

Weigley, Russell F. The American Way of War: A History of United States Military Strategy and Policy. Indiana University Press paperback edition. Bloomington: Indiana University Press, 1977.

William Thaddeus Sexton. Soldiers in the Sun. The Military Service Publishers Company, 1939.

Wolff, Leon. Little Brown Brother: How the United States Purchased and Pacified the Philippine Islands at the Century's Turn. New York, N.Y.: History Book Club, 2006. 


\section{CURRICULUM VITAE}

Name: $\quad$ Daniel Michael

Address: $\quad$ Cody Firearms Museum

720 Sheridan Avenue Cody, Wyoming 82414

DOB: Winchester, Virginia - December 28, 1987

Education: M.A., Public History

University of Louisville

2014-2017

B.A., History

Cedarville University

2006-2010

Work: Assistant Curator

Cody Firearms Museum

Cody, Wyoming

2016-Present

Curatorial Assistant

Frazier History Museum

Louisville, Kentucky

2014-2016 